\title{
Transcriptome analyses of ovarian stroma: tunica albuginea, interstitium and theca interna
}

\author{
Katja Hummitzsch ${ }^{1}$, Nicholas Hatzirodos ${ }^{1}$, Anne M Macpherson ${ }^{1}$, Jeff Schwartz ${ }^{2}$, \\ Raymond J Rodgers ${ }^{1}$ and Helen F Irving-Rodgers ${ }^{1,3}$ \\ ${ }^{1}$ Discipline of Obstetrics and Gynaecology, School of Medicine, Robinson Research Institute, The University of \\ Adelaide, Adelaide, South Australia, Australia, ${ }^{2}$ School of Medicine, Griffith University, Gold Coast, Queensland, \\ Australia and ${ }^{3}$ School of Medical Science, Griffith University, Gold Coast, Queensland, Australia \\ Correspondence should be addressed to H F Irving-Rodgers; Email: h.irving-rodgers@griffith.edu.au
}

\begin{abstract}
The ovary has specialised stromal compartments, including the tunica albuginea, interstitial stroma and theca interna, which develops concurrently with the follicular antrum. To characterise the molecular determinants of these compartments, stroma adjacent to preantral follicles (pre-theca), interstitium and tunica albuginea were laser microdissected ( $n=4$ per group) and theca interna was dissected from bovine antral follicles $(n=6)$. RNA microarray analysis showed minimal differences between interstitial stroma and pre-theca, and these were combined for some analyses and referred to as stroma. Genes significantly upregulated in theca interna compared to stroma included INSL3, LHCGR, HSD3B1, CYP17A1, ALDH1A1, OGN, POSTN and ASPN. Quantitative RT-PCR showed significantly greater expression of $O G N$ and LGALS1 in interstitial stroma and theca interna versus tunica and greater expression of $A C D$ in tunica compared to theca interna. PLN was significantly higher in interstitial stroma compared to tunica and theca. Ingenuity pathway, network and upstream regulator analyses were undertaken. Cell survival was also upregulated in theca interna. The tunica albuginea was associated with GPCR and cAMP signalling, suggesting tunica contractility. It was also associated with TGF- $\beta$ signalling and increased fibrous matrix. Western immunoblotting was positive for OGN, LGALS1, ALDH1A1, ACD and PLN with PLN and OGN highly expressed in tunica and interstitial stroma (each $n=6)$, but not in theca interna from antral follicles $(n=24)$.

Immunohistochemistry localised LGALS1 and POSTN to extracellular matrix and PLN to smooth muscle cells. These results have identified novel differences between the ovarian stromal compartments.

Reproduction (2019) 157 545-565
\end{abstract}

\section{Introduction}

Ovarian function is important for female health and reproduction. Much is known about the endocrine and paracrine signalling of ovarian development and function, particularly the factors that regulate the important events of ovarian organogenesis (Pepling 2012, Liu et al. 2015, Suzuki et al. 2015), follicle activation, growth and ovulation (Edson et al. 2009, Scaramuzzi et al. 2011, Hsueh et al. 2015, Monniaux 2016) and corpus luteum formation and regression (Pate et al. 2012). In addition, physical changes to the internal environment of the ovary may also influence follicle dynamics (Woodruff \& Shea 2011, Shea et al. 2014). Unlike the oocyte and membrana granulosa, which are anatomically distinct, the theca is a heterogeneous tissue compartment contiguous with the ovarian interstitial stroma. An important stage in follicle maturity is the vascularisation of the theca interna and acquisition of steroidogenic potential by thecal cells, coincident with formation of the serum-derived fluid within the antral cavity. In contrast to the current understanding of oocyte and granulosa cell maturation (Khan et al. 2016), the dynamics of the organisation and differentiation of the theca are poorly understood (Braw-Tal \& Roth 2005, Orisaka et al. 2006a,b, Honda et al. 2007, Young \& McNeilly 2010, Liu et al. 2015). In addition, developmental studies undertaken in mice may not adequately reflect ovarian formation or growth as it occurs in larger mammals (Jimenez 2009) and the existence of stem or progenitor cells in the ovary is an area only now becoming the object of investigation (Honda et al. 2007, Lee et al. 2013, Hummitzsch et al. 2015a, Adib \& Valojerdi 2017, Truman et al. 2017). Previous studies have found that granulosa cells influence the expression of thecal markers in cells harvested from whole neonatal mouse ovaries (Honda et al. 2007) and bovine ovarian cortex, but not medulla (Orisaka et al. 2006b), suggesting the presence of thecal progenitor cells in the cortex.

Laser capture microdissection (LCM) is a powerful new technology that allows the precise selection of 
targeted groups of cells based upon their location and appearance in tissue sections. In organs such as the ovary, which contains various types of cells and follicles at different developmental stages, LCM provides unique capabilities for isolating specific cells and structures, following changes in space and time. It had been applied successfully to identify and collect specific cells to enable studies of the expression of genes in fetal (Bocca et al. 2008) and adult oocytes (Markholt et al. 2012) and granulosa cells (Simpson et al. 2001, Bonnet et al. 2011, 2013), as well as of follicles at different maturational time points, including comparisons of cells from wildtype and oestrogen receptor beta-null ovaries (Binder et al. 2013) and the ovarian surface epithelium (Bowen et al. 2009). Despite this progress, to date, the collection of RNA of sufficient quality for microarray from thecal cells has been problematic (Binder et al. 2013).

Although our previous transcriptomic studies of the bovine theca interna have examined changes during follicular growth from small-to-large antral sizes (Hatzirodos et al. 2014a) and atresia (Hatzirodos et al. 2014b) as well as thecal cells treated with $\mathrm{LH}$ and/or BMP6 (Glister et al. 2013); however, less is known about the other stromal compartments of the ovary. The initial objective of the present study was to identify the differences in gene expression indicative of the transition from preantral to antral stages during follicular development and in the tunica albuginea. Gene expression of cell samples from ovaries of cycling cows was compared following hybridisation of cDNA to Affymetrix bovine gene arrays as described previously (Hatzirodos et al. 2015). Samples obtained by LCM were collected from the stroma adjacent to preantral follicles (pre-theca), the interstitial stroma between follicles, and the tunica albuginea, while theca interna of small antral follicles were collected by microdissection. To confirm differential gene expression, quantitative realtime PCR was performed on samples of tunica albuginea, interstitial stroma and theca interna. Protein levels and/or localisation were estimated by Western immunoblot and immunohistochemistry, respectively. Due to similarity of expression by interstitium and the stroma surrounding preantral follicles these two groups were combined and compared to the tunica albuginea and theca interna.

\section{Materials and methods}

\section{Tissues}

Bovine ovaries (one per animal) were collected at a local abattoir (Thomas Foods International, Murray Bridge, SA, Australia) from non-pregnant Bos taurus cows, within $20 \mathrm{~min}$ of slaughter and transported to the laboratory on ice. Because preantral follicles are too small for accurate manual dissection, laser capture was used to harvest the pre-theca, tunica and interstitial stroma for the initial microarray analysis. In order to harvest sufficient tissue for qRT-PCR and Western immunoblot and be consistent with our previous studies (Hatzirodos et al.
$2014 b)$, the theca interna of antral follicles, interstitium and tunica albuginea were also collected by microdissection.

For laser capture and microarray analyses of pre-theca, interstitium and tunica albuginea, strips of ovarian cortex were cut from each ovary and placed surface-side down into cryomolds (Miles Inc., Elkhart, IN, USA), containing optimal cutting temperature (OCT) compound (ProSciTech, Thuringowa central, QLD, Australia), frozen on dry ice and stored at $-80^{\circ} \mathrm{C}$.

For isolation of RNA from dissected samples, bovine thecal interna from small antral healthy follicles $(<5 \mathrm{~mm} ; n=7$ follicles from five animals for qRT-PCR and $n=6$ follicles from another four different animals for microarray analyses), interstitium between small follicles ( $n=6-7$ follicles from 6 to 7 different animals) and tunica albuginea ( $n=7-8$ follicles from 7 to 8 different animals) samples were dissected from the ovary. The RNA from dissected interstitium and tunica albuginea was subsequently used for qRT-PCR and the dissected theca interna was used for both microarray analyses and qRT-PCR.

\section{Classification of follicles in sections}

For the estimation of follicle dimensions, haematoxylin and eosin-stained $4 \mu \mathrm{m}$ paraffin or $10 \mu \mathrm{m}$ frozen serial sections were viewed with an Olympus BX50 microscope (Olympus) and a Spot RT digital camera and software used to measure the maximum follicle and oocyte diameter (Diagnostic Instruments, Sterling Heights, MI, USA).

\section{Laser capture microdissection}

Serial frozen sections of $10 \mu \mathrm{m}$ thick were cut using a CM1 800 cryostat (Leica Microsystems). Cryosections used for laser capture microdissection (LCM) were placed onto room temperature PET (polyethylene terephthalate) membrane frame slides (Leica Microsystems) and stored individually with desiccant in $50 \mathrm{~mL}$ tubes. Slides were fixed in $70 \%$ ethanol in DEPC-treated water, stained in $1 \%$ cresyl violet acetate $(\mathrm{pH}$ 7.75) (ProSciTech) in $70 \%$ ethanol (Cummings et al. 2011), washed for 30 s with 70,90 and $100 \%$ ethanol, followed by $1 \mathrm{~min}$ in $100 \%$ ethanol and stored overnight at $-80^{\circ} \mathrm{C}$ in a parafilm-sealed $50 \mathrm{~mL}$ tube with desiccant. Slides were thawed for $15 \mathrm{~min}$ at $-20^{\circ} \mathrm{C}$ followed by $15 \mathrm{~min}$ at $4^{\circ} \mathrm{C}$ immediately prior to LCM (LMD AS, Leica Microsystems). Excised samples were collected into $25 \mu \mathrm{L}$ of Ambion lysis solution for RNA isolation (Invitrogen). Pre-thecal tissue, measuring approximately $0.038 \mathrm{~mm}^{2}$ per follicle, was collected from 11 preantral follicles showing a visible oocyte and 2-3 layers of granulosa cells and a diameter $<400 \mu \mathrm{m}$. In each case, ovarian stromal tissue adjacent to the follicle was collected separately, as well as tissue from the tunica albuginea. Four samples per tissue type collected from 1 to 3 animals per sample (12 samples in total, from 11 animals) were used for RNA isolation (Table 1) for microarray analyses.

\section{RNA isolation and microarray hybridisation}

In addition to the samples collected by LCM, RNA was also isolated from six thecal tissue samples dissected from healthy antral follicles $<5 \mathrm{~mm}$ in diameter (six samples in total, from 
Table 1 Bovine ovarian samples used for microarray analysis.

\begin{tabular}{lccc}
\hline $\begin{array}{l}\text { Tissue origin/sample } \\
\text { number }\end{array}$ & $\begin{array}{c}\text { Animal } \\
\text { number }\end{array}$ & $\begin{array}{c}\text { Concentration } \\
(\mathrm{pg} / \mu \mathrm{L})\end{array}$ & $\begin{array}{c}\text { RNA integrity } \\
\text { number }\end{array}$ \\
\hline Stroma close to follicle & & & \\
S1 & 1 & 140 & 6.1 \\
S2 & 2 & 126 & 6.2 \\
S3 & 3 & 144 & 4.9 \\
S4 & $4,5,6$ & 133 & 5.6 \\
Interstitial stroma & & & \\
IS1 & 6,7 & 146 & 4.8 \\
IS2 & $4,5,8$ & 153 & 6.5 \\
IS3 & 9 & 160 & 5.5 \\
IS4 & 10,11 & 132 & 5.9 \\
Tunica albuginea & & & \\
T1 & 6,7 & 89 & 5.0 \\
T2 & $4,5,8$ & 129 & 5.9 \\
T3 & 9 & 190 & 5.5 \\
T4 & 10,11 & 127 & 6.3 \\
Theca interna from small & & & \\
antral follicles (<5 mm) & & & \\
T10 & 12 & 200 & $>8.0$ \\
T11 & 13 & 200 & $>8.0$ \\
T12 & 14 & 200 & $>8.0$ \\
T16 & 12 & 200 & $>8.0$ \\
T17 & 15 & 200 & $>8.0$ \\
T18 & 16 & 200 & $>8.0$ \\
\hline & & & \\
\hline & & & \\
\hline
\end{tabular}

four animals) and subjected to microarray analyses. Total RNA was extracted from thecal samples using RNeasy mini kits (Qiagen). The concentration of RNA was determined by spectrophotometric measurement at $260 \mathrm{~nm}$. For each preparation, $5 \mu \mathrm{g}$ of RNA was incubated with $1 \mu \mathrm{L}$ of DNase I $\left(2 \mathrm{U} / \mu \mathrm{L}\right.$ Ambion) at $37^{\circ} \mathrm{C}$ for $20 \mathrm{~min}$, and then treated with DNase inactivation reagent (Ambion) according to manufacturers' instructions.

Total RNA was extracted from the laser-dissected samples

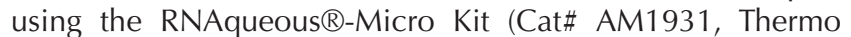
Fisher Scientific) procedure for LCM. The RNA derived from the laser-dissected samples (2-4ng) was DNase treated similarly as above.

RNA integrity was assessed with the Experion ${ }^{\text {TM }}$ automated electrophoresis system (Bio-Rad) (Table 1). All samples were then amplified and CDNA generated with the Ovation ${ }^{\circledR}$ Pico WTA System V2 (NuGEN, San Carlos, CA, USA) from an original amount of $5 \mu \mathrm{L}$ each of $100-200 \mathrm{pg} / \mu \mathrm{L}$ per sample prior to labelling for hybridisation at the Ramaciotti Centre for Genomics (The University of New South Wales, NSW, Australia).

Following confirmation of the quality of the RNA and cDNA synthesis, hybridisation to bovine gene $1.0 \mathrm{ST}$ Arrays (Affymetrix) and scanning were performed according to Affymetrix protocols at the Ramaciotti Centre for Genomics, briefly described below. cDNA was fragmented and labelled using the Encore Biotin Module kit (NuGEN) and used to hybridise against each array. The arrays were then washed and stained with streptavidin-phycoerythrin (final concentration $10 \mu \mathrm{g} / \mathrm{mL}$ ). The signal was amplified by biotinylated anti-streptavidin antibody, and arrays were scanned according to the manufacturer's instructions. The scanned images were inspected for the presence of any defects on the arrays.

\section{Data normalisation and analyses}

Affymetrix CEL files were imported into Partek Genomics Suite Software version 6.5 (Partek Incorporated, St Louis, MO, USA) and all 18 microarrays passed the quality assessment procedure. Raw expression data was normalised using prebackground adjustment for GC content, RMA background correction (Robust Multi-array Average) with quantile normalisation, log base 2 transformation and mean probe set summarisation with adjustment for GC content. For initial statistical analysis, the data were first subjected to Principal Component Analysis (PCA, based on the method of Joliffe (Jolliffe 1986)) using the correlation method for the dispersion matrix, and the normalised method for Eigenvector scaling. The overall gene expression in pre-thecal samples and interstitial stroma was very similar by PCA analysis, so these two groups were combined for subsequent analyses and termed stroma.

The expression data were analysed by one-way ANOVA using the Method of Moments estimation (Eisenhart 1947) with post hoc FDR or Bonferroni test for multiple comparisons as implemented by Partek. The fold change in expression for each gene was based on the ratio of signal intensity of the base 2 antilog mean values. Fisher's least significant difference (LSD) contrast method was used to compare theca interna versus stroma and tunica albuginea versus stroma. Differentially expressed gene data sets were imported into Ingenuity Pathway Analysis (IPA; Qiagen) and subjected to core analyses focussing on direct and indirect relationships pertaining to canonical pathways (metabolic and cell signalling), upstream regulators and network generation of differentially expressed gene interactions with other molecules within the Ingenuity Knowledge Base.

\section{Quantitative real-time PCR (qRT-PCR) for validation of microarray analyses}

RNA was extracted from dissected bovine theca interna from small antral healthy follicles ( $<5 \mathrm{~mm} ; n=7$ from five animals), interstitial stroma between small follicles $(n=6-7$ from 6 to 7 different animals) and tunica albuginea ( $n=7-8$ from 7 to 8 different animals). Follicle health was assessed as previously described (Hatzirodos et al. 2014a), based upon the absence of degenerative cells in a sample of the follicle wall. Samples were homogenised in $0.5 \mathrm{~mL}$ or $1 \mathrm{~mL}$ of TRIzol (Cat \# 15596026, Thermo Fisher Scientific), each for two $40 \mathrm{~s}$ cycles at $3500 \mathrm{rpm}$ in a PowerLyzer ${ }^{(B)} 24$ Bench Top Bead-Based Homogeniser (MoBio, Carlsbad, CA, USA). The samples were then processed according to the standard TRIzol protocol and resuspended in $20 \mu \mathrm{L}$ of nuclease-free $\mathrm{H}_{2} \mathrm{O}$. Ten micrograms or less of each sample was treated with $2 \mathrm{U}$ of DNase I for $20 \mathrm{~min}$ at $37^{\circ} \mathrm{C}$ and the enzyme removed using DNase inactivation reagent (Thermo Fisher Scientific). Two hundred nanograms of DNase-treated RNA was used for reverse transcription reactions with or without Superscript RT III (Thermo Fisher Scientific) to generate cDNA or a negative control to detect genomic contaminant respectively.

Quantitative real-time PCR of the cell samples for the target genes and the housekeeping genes GAPDH, RPL19 and RPL32 was performed using a Rotor-Gene 6000 series 1.7 thermal cycler (Corbett Life Science, Concord, NSW, Australia). cDNA 
dilutions were amplified in $10 \mu \mathrm{L}$ reactions containing $5 \mu \mathrm{L}$ of Power SYBR ${ }^{\mathrm{TM}}$ Green PCR Master Mix (Applied Biosystems/ Life Technologies), $0.2 \mu \mathrm{L}$ or $0.3 \mu \mathrm{L}$ each of reverse and forward primers (Geneworks; Table 2), respectively, $2 \mu \mathrm{L}$ of the $1 / 10$ CDNA dilution and $2.6 \mu \mathrm{L}$ or $2.4 \mu \mathrm{L}$ of DEPC-treated water. PCR amplification of the cDNA samples was carried out in duplicate at $95^{\circ} \mathrm{C}$ for $15 \mathrm{~s}$, followed by $60^{\circ} \mathrm{C}$ for $60 \mathrm{~s}$ for a total of 40 cycles. The Rotor-Gene 6000 software (Q Series, Qiagen) was used to determine the cycle threshold (Ct) values at a threshold of 0.05 normalised fluorescence units. Gene expression was determined by the mean of $2^{-\Delta \mathrm{Ct}}$, where $\Delta \mathrm{Ct}$ represents the target gene $\mathrm{Ct}-$ (Mean of GAPDH and RPL19 or RPL32) Ct.

\section{Immunohistochemistry}

Portions of ovaries embedded in OCT compound or paraffin were used for antigen localisation or co-localisation using indirect immunofluorescence. Ten micrometer sections were cut from each of the frozen ovaries using a CM1800 Leica cryostat (Leica Microsystems) and collected on Superfrost glass slides (HD Scientific Supplies, Glengala, Victoria, Australia) and stored at $-20^{\circ} \mathrm{C}$ until use. Unfixed sections were dried under vacuum for $5 \mathrm{~min}$ followed by fixation in $10 \%$ buffered formalin. After fixation, sections were rinsed in three $5 \mathrm{~min}$ changes of PBS $(10 \mathrm{mM}$ sodium/potassium phosphate with $0.274 \mathrm{M} \mathrm{NaCl}, 5 \mathrm{mM} \mathrm{KCl}$; $\mathrm{pH} 7.2$; hPBS) before treatment with blocking solution (10\% normal donkey serum (D-9663); Sigma Chemical Co.) in antibody diluent containing $0.55 \mathrm{M}$ $\mathrm{NaCl}$ and $10 \mathrm{mM}$ sodium phosphate $(\mathrm{pH} 7.1)$ for $20 \mathrm{~min}$ at RT. Paraffin-embedded ovaries were sectioned at $4 \mu \mathrm{m}$ on a CM1850 V2.2 Leica microtome, dewaxed and subjected to a pressure cooker antigen retrieval method (2100 retriever, Prestige Medical Ltd; Blackburn, United Kingdom) for 20 min in $10 \mathrm{mM}$ citrate buffer ( $\mathrm{pH}$ 6.0). Table 3 summarises details of the antibodies used, the fixation conditions and incubation conditions in primary antisera that were performed overnight at $4^{\circ} \mathrm{C}$. Sections were also treated with $3 \mu \mathrm{M} 4^{\prime}, 6^{\prime}$-diamidino2-phenylindole dihydrochloride (DAPI) solution (Molecular Probes) to identify cell nuclei. Sections were mounted in fluorescence mounting medium (S302380, Dako Australia Pty Ltd) and viewed with an Olympus BX63F microscope with epifluorescence attachment (Olympus Australia). Negative controls included those with no primary antiserum or non-immune mouse or rabbit sera (Dako). No staining was observed with these controls.

\section{Western immunoblotting}

Total protein was extracted from tunica albuginea $(n=6$ follicles from six animals), interstitial stroma between small follicles ( $n=6$ from 6 animals) and theca interna samples ( $n=16-20$ follicles with a diameter $<5 \mathrm{~mm}$ from seven animals) using RIPA buffer (1\% NP-40, 1\% sodium deoxycholate, $0.1 \%$ sodium dodecyl sulphate, $0.15 \mathrm{M}$ sodium chloride, $50 \mathrm{mM}$ Tris-hydrochloric acid and $1 \mathrm{mM}$ EDTA) containing protease inhibitor cocktail (\#P9599, Sigma-Aldrich). All samples were homogenised separately for two 20 s cycles at $3500 \mathrm{rpm}$ in a PowerLyzer $^{\circledR} 24$ Bench Top Bead-Based Homogeniser (MoBio).
Proteins were quantified using the Bradford method (BioRad Laboratories) and $20 \mu \mathrm{g}$ of protein for each sample were separated on SDS-gels (Any kD ${ }^{\mathrm{TM}}$ Mini-PROTEAN ${ }^{\circledR}$ TGX ${ }^{\mathrm{TM}}$ Precast Protein Gels, \#4569035, Bio-Rad Laboratories), and then transferred overnight at $4^{\circ} \mathrm{C}$ to PVDF transfer membrane (Amersham HybondTM-P, GE Healthcare), at a constant voltage (33 V). After protein visualisation with Ponceau red staining, the PVDF membrane was washed three times for $10 \mathrm{~min}$ at room temperature with Tris-buffered saline (TBS; $50 \mathrm{mM}$ Trishydrochloride, $100 \mathrm{mM}$ sodium chloride, $\mathrm{pH}$ 7.5) containing $0.05 \%$ Tween-20 (Sigma-Aldrich). Non-specific binding was inhibited by incubating with blocking buffer $(10 \%$ skim milk in TBS containing $0.5 \%$ Tween-20) for $1 \mathrm{~h}$ at RT. Membranes were then incubated with the primary antibodies (Table 3) for $2 \mathrm{~h}$ in blocking buffer. After incubation, membranes were washed three times for $10 \mathrm{~min}$ each with TBS containing $0.1 \%$ Tween-20 at RT. The membranes were then incubated for $1 \mathrm{~h}$ at room temperature with the appropriate secondary antibody: peroxidase-conjugated goat anti-rabbit IgG (diluted 1:10,000; \#AP132P; Merck Millipore) or peroxidase-conjugated goat anti-mouse IgG (diluted 1:10,000; \#A0168; Sigma-Aldrich), diluted in blocking buffer. After incubation with the secondary antibody, the membranes were washed three times for $10 \mathrm{~min}$ each with TBS containing $0.1 \%$ Tween-20 and subsequently twice for $10 \mathrm{~min}$ each in TBS containing $0.5 \%$ Tween-20 and $0.1 \%$ SDS. For visualisation, membranes were incubated with ECL Advance TM Western blotting detection reagent (GE Healthcare) for $5 \mathrm{~min}$ and exposed to Amersham Hyperfilm $\mathrm{ECL}$ and then scanned and quantified using image software Multi Gauge V3.0 (Fujifilm Life Sciences, Tokyo, Japan). Betaactin was used as a loading control.

\section{Deglycosylation of osteoglycin with N-Glycosidase F (PNGase F)}

After denaturation in $50 \mathrm{mM}$ Tris- $\mathrm{HCl}, \mathrm{pH} 6.8$, containing 1\% SDS and $1.4 \%$ beta-mercaptoethanol for 5 mins at $95^{\circ} \mathrm{C}, 20 \mu \mathrm{g}$ of total protein from interstitium $(n=4$, described in previous paragraph) were incubated with $2.5 \mathrm{U} / \mathrm{mL}$ PNGase F containing $15 \%$ Triton-X100 for $3 \mathrm{~h}$ at $37^{\circ} \mathrm{C}$. The reaction was stopped by incubation for $5 \mathrm{~min}$ at $95^{\circ} \mathrm{C}$. The samples were then separated by SDS-PAGE as described in the previous paragraph.

\section{Statistical analysis for qRT-PCR and Western blots}

All statistical calculations for qRT-PCR and Western blots were performed using Microsoft Office Excel 2010 (Microsoft), GraphPad Prism version 6.00 (GraphPad Software Inc.) and SPSS version 21 (IBM Australia). One-way ANOVA followed by Tukey's post hoc test were applied to look for significant differences between the different cell and tissue types. Values of $P<0.05$ were considered significant.

\section{Results}

\section{Follicle characterisation for LCM}

In order to aid the identification of preantral follicles, size was determined from $4 \mu \mathrm{m}$ serial sections of paraffin-embedded ovaries. The maximum oocyte and 


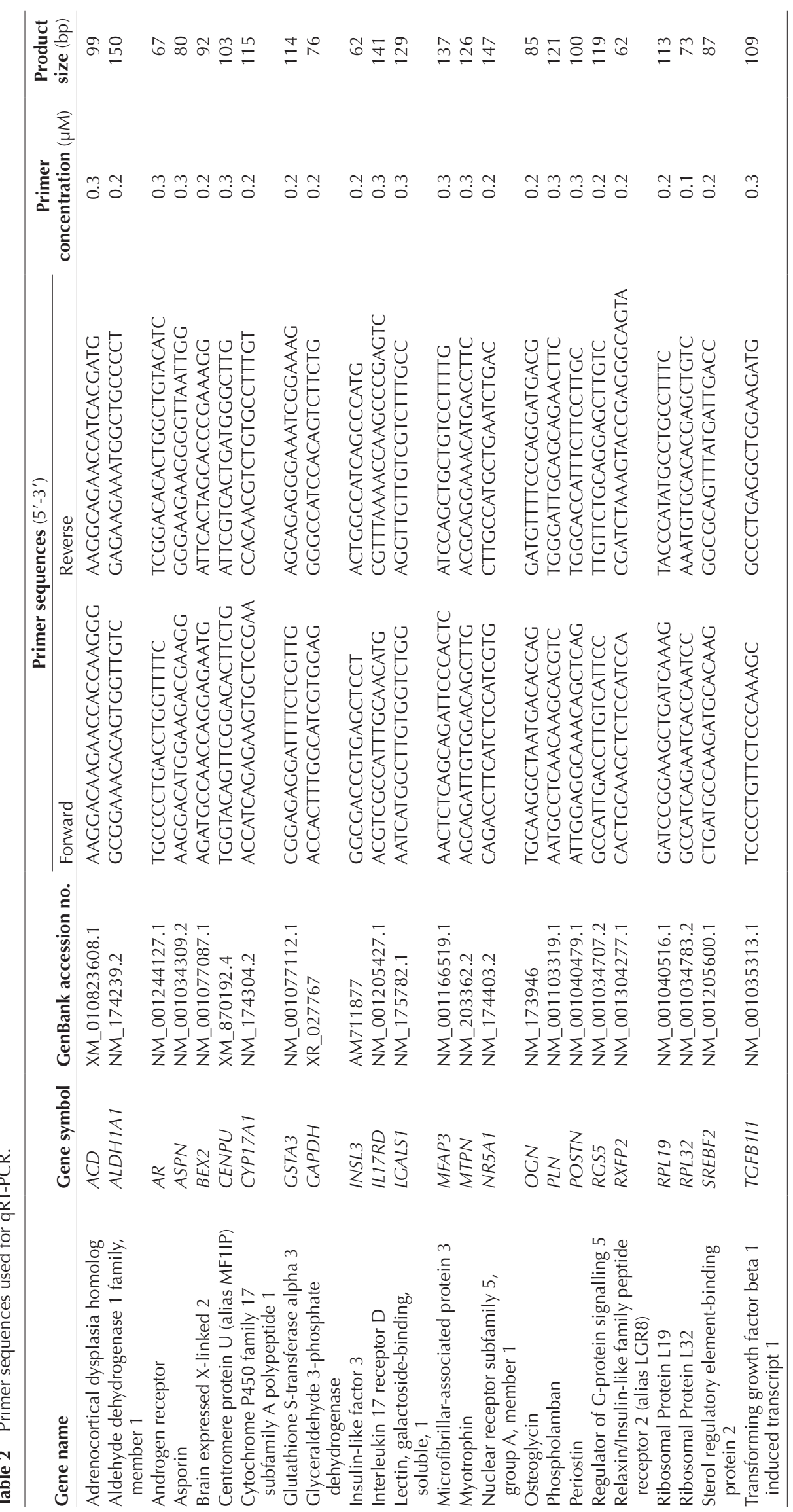


Table 3 Summary of primary antibodies used for Western blot and immunohistochemistry.

\begin{tabular}{|c|c|c|c|c|}
\hline $\begin{array}{l}\text { Antigen } \\
\text { (species) }\end{array}$ & $\begin{array}{l}\text { Host species, code/clone number, } \\
\text { epitope sequence, source }\end{array}$ & $\begin{array}{l}\text { Western blot } \\
\text { (concentration } \\
\text { or dilution) } \\
\end{array}$ & $\begin{array}{l}\text { IHC fixation, } \\
\text { concentration or } \\
\text { dilution }\end{array}$ & $\begin{array}{l}\text { Secondary antibody* (catalogue number)/ } \\
\text { conjugated fluorophores (catalogue number) }\end{array}$ \\
\hline Actin (chicken) & $\begin{array}{l}\text { Mouse, ab3280/ACTN05 (C4), from } \\
\text { chicken gizzard, Abcam }\end{array}$ & $0.1 \mu \mathrm{g} / \mathrm{mL}$ & $10 \%$ BFS, $2 \mu \mathrm{g} / \mathrm{mL}$ & $\begin{array}{l}\text { Biotin-SP-conjugated AffiniPure donkey } \\
\text { anti-mouse lgG (715-066-151)/Cy3-conjugated } \\
\text { streptavidin (016-160-084) }\end{array}$ \\
\hline $\begin{array}{l}\text { ACD/PTOP } \\
\text { (human) }\end{array}$ & $\begin{array}{l}\text { Rabbit, LS-C108067/70127, } \\
\text { aa476-516, LifeSpan BioSciences }\end{array}$ & $1 \mu \mathrm{g} / \mathrm{mL}$ & & \\
\hline $\begin{array}{r}\text { ALDH1A1 } \\
\text { (monkey) }\end{array}$ & $\begin{array}{l}\text { Rabbit, ab194588, aa202-501 } \\
\text { (C terminal), Abcam }\end{array}$ & $1.75 \mu \mathrm{g} / \mathrm{mL}$ & & \\
\hline $\begin{array}{l}\text { LGALS1 } \\
\text { (bovine) }\end{array}$ & $\begin{array}{l}\text { Rabbit, LS-C293992/71149, } \\
\text { aa1-135,LifeSpan BioSciences }\end{array}$ & $0.5 \mu \mathrm{g} / \mathrm{mL}$ & $10 \%$ BFS, $2 \mu \mathrm{g} / \mathrm{mL}$ & $\begin{array}{l}\text { Biotin-SP-conjugated AffiniPure donkey } \\
\text { anti-rabbit IgG }(711-066-152) / \text { Cy3-conjugated } \\
\text { streptavidin (016-160-084) }\end{array}$ \\
\hline OGN (human) & $\begin{array}{l}\text { Rabbit, MBS92306, synthetic } \\
\text { peptide conjugated to KLH within } \\
\text { residues 246-276 (C-terminus), } \\
\text { MyBioSource }\end{array}$ & $1: 1000$ & & \\
\hline PLN (human) & $\begin{array}{l}\text { Mouse, sc-398631/ F-10, amino } \\
\text { acids 537-836 (C-terminus), Santa } \\
\text { Cruz Biotechnology Inc }\end{array}$ & & $10 \%$ BFS, $2 \mu \mathrm{g} / \mathrm{mL}$ & $\begin{array}{l}\text { Biotin-SP-conjugated AffiniPure donkey } \\
\text { anti-rabbit IgG (711-066-152)/ Cy3-conjugated } \\
\text { streptavidin (016-160-084) }\end{array}$ \\
\hline PLN (human) & $\begin{array}{l}\text { Rabbit, MBS9206238, synthetic } \\
\text { peptide conjugated to KLH within } \\
\text { residues } 1-22 \text { (N-terminus), } \\
\text { MyBioSource }\end{array}$ & $0.03 \mu \mathrm{g} / \mathrm{mL}$ & $\begin{array}{l}10 \% \mathrm{BFS} \\
1.25 \mu \mathrm{g} / \mathrm{mL}\end{array}$ & $\begin{array}{l}\text { Biotin-SP-conjugated AffiniPure donkey } \\
\text { anti-rabbit lgG (711-066-(152)/ Cy3- } \\
\text { conjugated streptavidin (016-160-084) }\end{array}$ \\
\hline $\begin{array}{r}\text { Perlecan } \\
\text { (mouse) }\end{array}$ & $\begin{array}{l}\text { Rat, MAB1948/ A7L6, heparin } \\
\text { sulphate proteoglycan from EHS } \\
\text { mouse tumour, Millipore }\end{array}$ & & $\begin{array}{l}10 \% \mathrm{BFS} \\
10 \mu \mathrm{g} / \mathrm{mL}\end{array}$ & $\begin{array}{l}\text { FITC-conjugated AffiniPure donkey anti-rat } \\
(712-096-153)\end{array}$ \\
\hline $\begin{array}{l}\text { Smooth } \\
\text { muscle actin } \\
\text { (human) }\end{array}$ & $\begin{array}{l}\text { Mouse, M0951/ 1A4, synthetic } \\
\text { peptide conjugated to KLH } \\
\text { (N-terminal), Dako }\end{array}$ & & 10\% BFS, 1:100 & $\begin{array}{l}\text { FITC-conjugated AffiniPure donkey anti-mouse } \\
(715-096-151)\end{array}$ \\
\hline Lectin & $\begin{array}{l}\text { From Bandeiraea simplicifolia, } \\
\text { L9381, Sigma }\end{array}$ & & $\begin{array}{l}10 \% \mathrm{BFS}, \\
10 \mu \mathrm{g} / \mathrm{mL}\end{array}$ & FITC conjugate \\
\hline
\end{tabular}

$10 \%$ BFS is $10 \%$ formalin in phosphate buffered saline.

*All secondary antibodies and fluorophores for immunohistochemistry were sourced from Jackson ImmunoResearch Laboratories Inc. (West Grove, PA, USA) and used at 1:100. "Perlecan was used as a basement membrane marker (McArthur et al. 2000).

$\mathrm{IHC}$, immunohistochemistry.

follicle diameter was measured for preantral $(n=117)$, early antral $(n=12)$ and antral follicles $(n=56)$. The diameter of follicles identified as preantral $(377+78 \mu \mathrm{m})$ was significantly less than early antral $(526+98 \mu \mathrm{m})$ and antral $(606+29 \mu \mathrm{m})(P<0.001$, Fig. $1 \mathrm{~A})$, consistent with the dimensions previously reported for bovine follicles (Aerts \& Bols 2010). Oocytes of antral follicles were significantly larger than those of early antral $(P<0.01)$ or preantral follicles $(P<0.001)$ (Fig. 1A). The effect of formalin-fixed cryosections was assessed by comparing the cross-sectional area of primordial, primary, primarysecondary (transitional), secondary and preantral follicles to formalin-fixed paraffin-embedded ovarian sections (Fig. 1B). Cryosectioned ovaries had significantly smaller transitional and secondary follicles $(P<0.01$ and $P<0.001$, respectively) compared to paraffin sections. On the basis of these results a follicle diameter of $<400 \mu \mathrm{m}$ was chosen to identify preantral follicles when conducting the LCM.

\section{Statistical analyses of the microarray data}

Principal component analysis (PCA) for the first three components (Fig. 2) of all microarrays in this study was conducted. Interstitial stroma and pre-theca were similar, and therefore, they were subsequently treated as a single group, called 'stroma' $(n=8)$, for further analysis. PCA clearly separated the stroma, the theca interna and the tunica albuginea into three separate clusters (Fig. 2). Stroma was compared to the theca interna and the tunica albuginea. The array intensities for all genes from the microarray analysis are shown in Supplementary Table 1 (see section on supplementary data given at the end of this article).

Comparing theca interna from small antral follicles to stroma, there were 654 differentially expressed probe IDs (arbitrary fold change threshold of 3, Bonferroni correction for multiple testing, $P<0.05$ ), with 534 of these mapped to Entrez gene IDs with three sets of duplicate probes, leaving 279 upregulated genes (Table 4) and 252 downregulated genes (Table 5) in the theca interna.

Comparing tunica albuginea to stroma, there were 365 differentially expressed probe IDs (arbitrary fold change threshold of 2, FDR correction for multiple testing, $q<0.05-i$.e. less stringent cut-off points than for the theca interna versus stroma comparison analyses), with 295 of these mapped to Entrez gene IDs with one set of duplicate probes, leaving 174 upregulated genes (Table 6) and 120 downregulated genes (Table 7) in the tunica albuginea. 

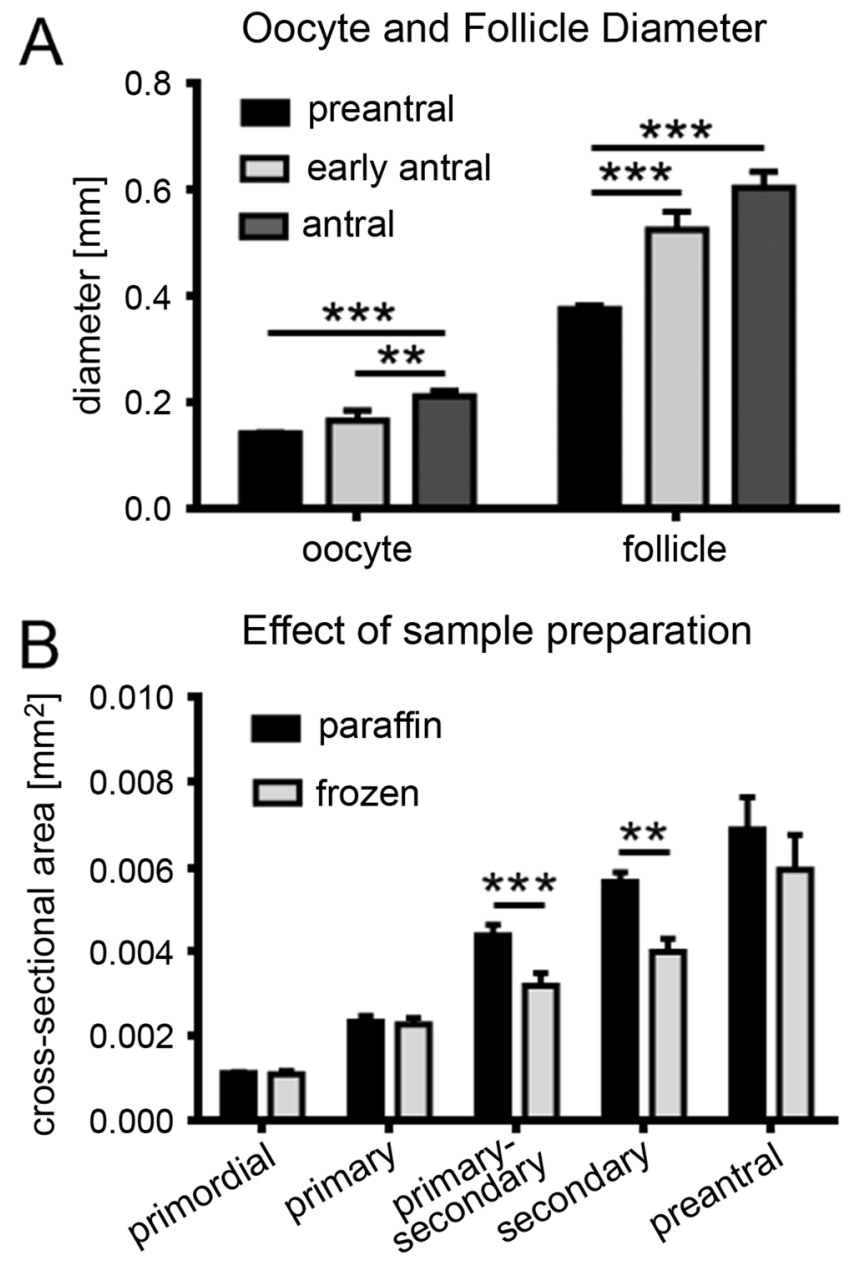

Figure 1 Follicle characterisation. (A) In H\&E-stained paraffin sections, the diameter of oocyte and follicle was measured for preantral $(n=117)$, early antral $(n=12)$ and antral $(n=56)$ follicles. Significantly different results between follicle types were determined by one-way ANOVA with Tukey's post hoc test. ${ }^{* *} P<0.01$,

$* * * P<0.001$. (B) Comparisons of formalin fixation with paraffin embedding versus formalin fixation with OCT embedding on follicle diameter is shown for primordial ( $n=65$ and $n=14$, respectively), primary ( $n=29$ and $n=15$, respectively), primary to secondary ( $n=7$ and $n=8$, respectively), secondary $(n=8)$ and preantral $(n=5)$ follicles. Significantly different results between paraffin and frozen were determined by independent $t$ test. ${ }^{* *} P<0.01,{ }^{* * *} P<0.001$.

\section{Validation of microarray analysis by $q R T-P C R$}

To confirm changes in the expression of genes identified by microarray analysis, qRT-PCR analyses was performed on dissected samples of tunica albuginea, interstitial stroma and theca interna (Fig. 3). Microarray analysis showed three thecal-specific genes (CYP17A1, INSL3 and its receptor RXFP2) were highly expressed in the theca interna compared to the other compartments and the same pattern was observed in the qRT-PCR results (Fig. 3A, B, C and D). One gene, ALDH1A1, was found significantly highly expressed in the theca in the microarray but was not significantly different as assessed by qRT-PCR. Two genes, BEX2 and SRBF2,

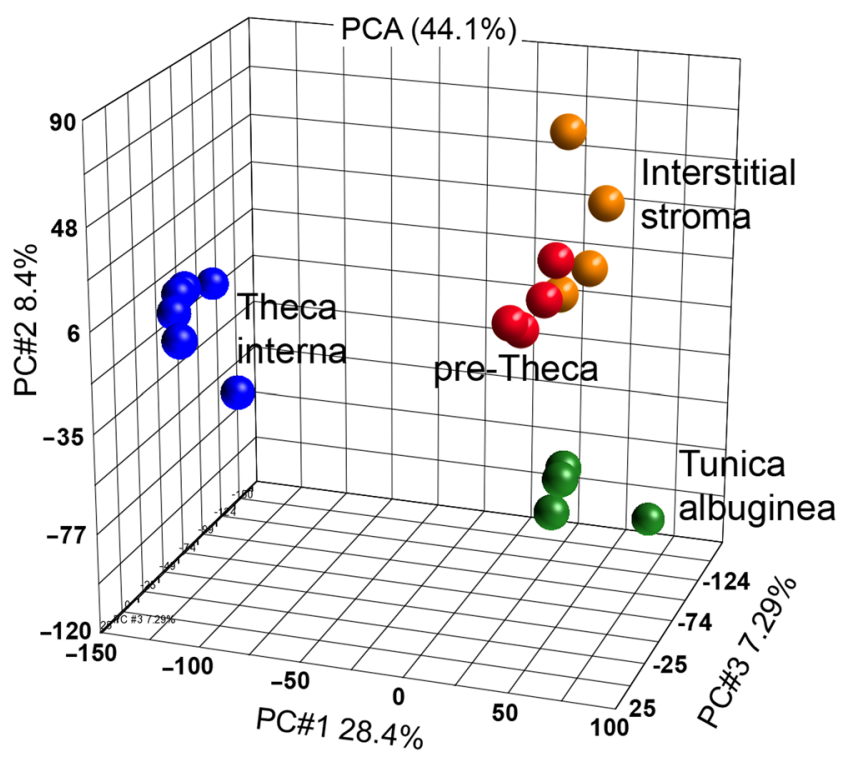

Figure 2 Unsupervised PCA of arrays from interstitial stroma $(n=4)$, pre-theca $(n=4)$, theca interna $(n=6)$ and tunica albuginea $(n=4)$. Each point represents a microarray chip and are separated by tissue type. The graph is a scatter plot of the values for the first (X-axis), second (Y-axis) and third (Z-axis) principal components based on the Pearson correlation matrix of the total normalised array intensity data.

which showed no differential expression between the four compartments in the microarray analysis, were also unchanged between theca interna, interstitial stroma and tunica albuginea in the qRT-PCR (Fig. 3E and F).

\section{Pathway, network and upstream regulator analyses}

The canonical pathways indicated by IPA most likely to be affected by differential gene expression in the theca interna of small antral follicles compared to stroma was an upregulation of genes associated with steroid hormone (androgen and glucocorticoid biosynthesis) and cholesterol synthesis (Fig. 4A). On the other hand, genes in our dataset associated with hepatic fibrosis/ hepatic stellate activation, including TGF $\beta$ signalling and regulation of epithelial-mesenchymal transition, were downregulated in the theca interna. For the tunica albuginea versus stroma dataset, the top canonical pathways were associated mainly with hepatic fibrosis/ hepatic stellate activation and GPCR cAMP signalling (Fig. 4B). Furthermore, most of these genes were upregulated in the tunica albuginea compared to stroma. The proportion of genes altered in these pathways is found in Fig. 4 and individual genes from our datasets which are involved in these canonical pathways are presented in Supplementary Table 2 for theca interna versus stroma, and in Supplementary Table 3 for tunica albuginea versus stroma.

The top three networks generated by IPA from the theca interna versus stroma dataset are shown in Fig. 5 
Table 4 Top 100 genes differentially upregulated in theca interna from small antral follicles compared to stroma (interstitial stroma and pre-theca).

\begin{tabular}{|c|c|c|c|c|c|}
\hline Gene symbol & Fold change & Gene symbol & Fold change & Gene symbols & Fold change \\
\hline INSL3 & 157.8 & PIK3R3 & 13.4 & PTCH1 & 8.8 \\
\hline LHCGR & 85.3 & CD36 & 13.2 & CTSC & 8.8 \\
\hline HSD3B1 & 71.9 & HHIP & 12.0 & IQGAP2 & 8.6 \\
\hline CXCL14 & 52.5 & $O M D$ & 11.9 & DFNA5 & 8.5 \\
\hline LOC104968612 & 49.8 & DHCR24 & 11.7 & PTPRB & 8.4 \\
\hline GSTA3 & 46.5 & CENPA & 11.5 & TMEM254 & 8.4 \\
\hline MT1E & 38.0 & CEP55 & 11.5 & FAM129A & 8.3 \\
\hline KCNIP1 & 29.3 & ARHGAP11A & 11.3 & DIAPH3 & 8.3 \\
\hline S100A2 & 27.0 & FBLN5 & 11.2 & $A N L N$ & 8.2 \\
\hline$A D A M D E C 1$ & 26.4 & TPX2 & 11.1 & GPM6A & 8.0 \\
\hline APOA1 & 26.2 & ENTPD1 & 11.0 & CLEC $3 B$ & 8.0 \\
\hline TOP2A & 25.4 & CENPE & 11.0 & LOC508666 & 7.7 \\
\hline MAL2 & 25.3 & $F S T$ & 10.4 & MS4A8 & 7.7 \\
\hline LOC104968446 & 23.3 & UBE2C & 10.3 & RAN & 7.6 \\
\hline ITGBL1 & 23.1 & CKAP2 & 10.3 & ZMAT4 & 7.3 \\
\hline$H P G D$ & 22.7 & RRM2 & 10.3 & KIAA0101 & 7.3 \\
\hline LOC104975684 & 20.4 & LIPG & 10.1 & $E R P 27$ & 7.2 \\
\hline$A L D H 1 A 1$ & 19.1 & CENPF & 9.8 & TM4SF18 & 6.9 \\
\hline$A S P N$ & 18.0 & CCL14 & 9.8 & KCNE4 & 6.9 \\
\hline PLD1 & 17.8 & PRR11 & 9.8 & INHA & 6.8 \\
\hline SLC16A7 & 16.8 & $R A B 38$ & 9.8 & PSMB9 & 6.8 \\
\hline KIF11 & 16.3 & IPO11 & 9.5 & NDC80 & 6.7 \\
\hline CATHL5 & 16.3 & SCG 2 & 9.5 & IDH1 & 6.7 \\
\hline GSTA5 & 16.1 & INHBA & 9.4 & THSD7A & 6.6 \\
\hline MKI67 & 15.7 & ASS1 & 9.3 & NCAPG & 6.5 \\
\hline OGN & 15.1 & ANGPTL5 & 9.3 & GRHL1 & 6.4 \\
\hline GRB14 & 15.0 & $D E P D C 1$ & 9.3 & CAV1 & 6.3 \\
\hline CAPN6 & 14.8 & $X D H$ & 9.2 & CHODL & 6.3 \\
\hline SLCO2A 1 & 14.8 & POSTN & 9.1 & $C M K L R 1$ & 6.3 \\
\hline SPC24 & 14.5 & LOC514257 & 9.0 & GJB5 & 6.3 \\
\hline TNNI3 & 13.9 & $A S P M$ & 8.9 & $A D K$ & 6.3 \\
\hline LOC527388 & 13.7 & STC1 & 8.9 & FIGF & 6.3 \\
\hline SLC25A5 & 13.6 & SECTM1A & 8.9 & & \\
\hline PAPSS2 & 13.5 & DCTPP1 & 8.8 & & \\
\hline
\end{tabular}

(Benjamini-Hochberg post hoc test for multiple corrections following one-way ANOVA). The fold change is the ratio of signal intensity of combined pre-theca and interstitial stroma to theca interna from microarray analyses. Differentially regulated genes $(>-3$ fold, $P<0.05)$ were annotated based on the Entrez Gene database. Genes are listed in descending order of fold change.

and the genes and their degree of change of expression are also indicated. The first relates to cellular assembly and organisation, the cell cycle and DNA functions and has ESR1 (oestrogen receptor alpha) at its centre and involves downregulation of NR1D1 (transcriptional repressor Rev-erbo) and upregulation of CITED1 (Cbp/p300-interacting transactivator 1) in the theca interna. The second pathway is cell cycle and neurological diseases and contains cell death genes like cytochrome $\mathrm{C}$ and caspase and protective or cell survival genes like SOD1, Hsp70, prohibitin $(P H B)$ and NUPR1/RELB/IER3 which is downregulated in theca interna. The third pathway has $E R K 1 / 2$ at is centre and also involves the upregulation of INSL3, $L O X$ and FBL5.

The top three networks for tunica albuginea versus stroma are shown in Fig. 6 and the genes and their degree of change of expression are also indicated. The first network of embryonic development has ERK1/2 at its centre but also contains upregulated calcium and potassium channels (CACNA1G, T-type calcium channel, KCND2) and prostaglandin-related genes PDGES (PGE2 synthase) and EPX1 (Epoxide hydrolase 1 that can synthesise arachidonic acid). The second network on cell morphology contains a number of upregulated extracellular matrix molecules ( $L A M B 1$, collagens type III and IV, COL1A2) and enzymes that process extracellular matrix (elastase, gelatinase, $P C O L C E)$ in the tunica albuginea. The third network is organ morphology and contains a number of upregulated growth factors including VEGF, NDP (norrin) and HGF, and transcription factor in Wnt signalling (TCF/LEF) and a considerable number of downregulated genes.

For theca interna versus stroma upstream transcriptional regulators analyses revealed 14 activated, including PTGER2 (prostaglandin E2), CDKN1B and RABL6 (cell cycle), NR5A1 (SF1), FSH and MTOR, and 24 inhibited upstream regulators, including NUPR1 (cell survival), IL1 and TNF $\alpha$, in the theca interna relative to stroma (Supplementary Table 4). 
Table 5 Top 100 genes differentially downregulated in theca interna from small antral follicles compared to stroma (interstitial stroma and pre-theca).

\begin{tabular}{|c|c|c|c|c|c|}
\hline Gene symbol & Fold change & Gene symbol & Fold change & Gene symbols & Fold change \\
\hline SFRP4 & -45.8 & MOB3B & -8.5 & $A D R A 1 B$ & -5.9 \\
\hline NUPR1 & -30.1 & PID1 & -8.3 & MFAP4 & -5.9 \\
\hline TUBA3E & -28.1 & TMOD1 & -8.2 & ALDH1L2 & -5.9 \\
\hline MUSTN1 & -26.2 & MIR29C & -8.0 & PLTP & -5.8 \\
\hline ENPEP & -26.2 & HTRA3 & -7.9 & TMOD2 & -5.8 \\
\hline FAIM2 & -24.5 & FBLN1 & -7.9 & ASTN1 & -5.7 \\
\hline$A D A D 1$ & -19.2 & $M X R A B$ & -7.8 & MITF & -5.7 \\
\hline OPCML & -18.5 & SMOC1 & -7.8 & C23H6orf25 & -5.7 \\
\hline GTSF1 & -17.9 & BEX4 & -7.7 & GABRB2 & -5.7 \\
\hline HOPX & -17.6 & FGL2 & -7.7 & ITIH4 & -5.6 \\
\hline$N R 4 A 1$ & -16.9 & CIART & -7.6 & $N R 3 C 2$ & -5.6 \\
\hline MIR99A & -14.5 & CHL1 & -7.2 & ANK3 & -5.5 \\
\hline MDGA2 & -14.4 & SETBP1 & -7.2 & $M E T$ & -5.4 \\
\hline MIRLET7C & -14.1 & EGR1 & -7.1 & $M A O B$ & -5.4 \\
\hline LOC100337251 & -12.1 & $B C L 2$ & -7.0 & IGFBP5 & -5.4 \\
\hline GNAO1 & -12.1 & $D A Z L$ & -7.0 & LIMCH1 & -5.4 \\
\hline C1S & -11.7 & FBXO32 & -7.0 & LOC505383 & -5.3 \\
\hline NR1D1 & -11.4 & RUNX1 & -6.9 & SMOC2 & -5.3 \\
\hline $\mathrm{COCH}$ & -11.2 & ROR1 & -6.9 & TMEM100 & -5.2 \\
\hline CPEB 1 & -11.1 & PCSK2 & -6.9 & MYOCD & -5.2 \\
\hline NTRK2 & -10.5 & UNC13C & -6.9 & MYH11 & -5.1 \\
\hline RGS2 & -10.4 & EQTN & -6.8 & FAT4 & -5.1 \\
\hline $\mathrm{CDH} 6$ & -10.1 & ID2 & -6.7 & CNN1 & -5.0 \\
\hline RASGEF1B & -9.4 & HGF & -6.7 & CHAD & -5.0 \\
\hline SEMA3D & -9.4 & WNT5A & -6.6 & $M D K$ & -5.0 \\
\hline PRELP & -9.4 & LOC505383 & -6.6 & C1R & -4.9 \\
\hline ITIH5 & -9.4 & SDC4 & -6.6 & LMCD1 & -4.9 \\
\hline PTGES & -9.3 & $N R 4 A 3$ & -6.5 & SEMA6A & -4.9 \\
\hline SCUBE3 & -9.2 & ATP1B2 & -6.5 & PROCA1 & -4.9 \\
\hline FABP7 & -9.1 & ITGB8 & -6.5 & SNCAIP & -4.9 \\
\hline GRM8 & -9.0 & GXYLT2 & -6.3 & CNTN1 & -4.8 \\
\hline TMEFF2 & -8.9 & $N R 4 A 2$ & -6.3 & $B A M B I$ & -4.8 \\
\hline CHI3L1 & -8.7 & $A M Y 2 B$ & -6.2 & WASF3 & -4.8 \\
\hline$T H R B$ & -8.6 & FGF10 & -6.1 & $A K R 1 C 4$ & -4.8 \\
\hline
\end{tabular}

(Benjamini-Hochberg post hoc test for multiple corrections following one-way ANOVA). The fold change is the ratio of signal intensity of combined pre-theca and interstitial stroma to theca interna from microarray analyses. Differentially regulated genes $(>3$ fold, $P<0.05)$ were annotated based on the Entrez Gene database. Genes are listed in descending order of fold change.

For tunica albuginea versus stroma, 26 upstream regulators were activated and 16 inhibited, such as SP600125 (JNK inhibitor), docosa-hexaenoic acid (which can be converted to epoxides and arachidonic acid), DHEA and ESR1 (Supplementary Table 5). The activated upstream regulators were mainly associated with TGF $\beta$ signalling (TGFB1-3, TGFBR1) and the immune system/response (lipopolysaccharide, IL1A, IL10RA, CXCL12, TLR4).

\section{Differentially expressed genes in theca interna compared to other stromal compartments}

Microarray analysis showed significant upregulation of OGN and LGALS1 in theca interna versus tunica albuginea, interstitium and pre-theca (Fig. 7A and B), whereas qRT-PCR indicted mRNAs for both genes were significantly upregulated in both theca interna and interstitium versus tunica albuginea (Fig. 7A and B). By microarray POSTN was found to be significantly upregulated in the theca interna (Fig. 7C); however, this was not confirmed by qRT-PCR $(P>0.07)$. ASPN was strongly upregulated in theca interna compared to tunica albuginea, interstitium and pre-theca in microarray analysis and qRT-PCR (Fig. 7D). qRT-PCR did not confirm the finding by microarray of upregulation of RGS5 in theca interna (Fig. 7E). However, the significant upregulation of the gene in interstitium compared to tunica albuginea was observed by both techniques.

Microarray analysis revealed a significant increase in expression of MFAP3 in theca interna, and a significant decrease in pre-theca compared to tunica albuginea and interstitium (Fig. 7F). However qRT-PCR showed a significant upregulation only in theca interna versus tunica albuginea. In contrast to the before mentioned genes, where the expression was upregulated in the theca interna, the expression of PLN was significantly downregulated in theca interna versus pre-theca by microarray analysis and versus interstitium by qRTPCR (Fig. 7G). There was also a significant difference 
Table 6 Top 100 genes differentially upregulated in tunica albuginea compared to stroma (interstitial stroma and pre-theca).

\begin{tabular}{|c|c|c|c|c|c|}
\hline Gene symbol & Fold change & Gene symbol & Fold change & Gene symbols & Fold change \\
\hline ADAM22 & 21.9 & TMEM132D & 3.3 & KHDRBS3 & 2.7 \\
\hline$T N C$ & 7.5 & GATA5 & 3.3 & $S R P X 2$ & 2.6 \\
\hline STRA6 & 7.0 & NCAM1 & 3.2 & CTPS1 & 2.6 \\
\hline HTR1D & 6.7 & GALNT3 & 3.2 & $M K X$ & 2.6 \\
\hline PENK & 6.3 & ARSI & 3.2 & PRSS12 & 2.6 \\
\hline PPP1R14C & 6.0 & FAM129A & 3.1 & $A L D H 1 A 1$ & 2.6 \\
\hline COL8A2 & 5.5 & ETV5 & 3.1 & CEACAM1 & 2.6 \\
\hline EPHX1 & 5.5 & STC1 & 3.1 & LOC101902670 & 2.6 \\
\hline$B G N$ & 5.1 & CYR61 & 3.0 & CHRM2 & 2.6 \\
\hline TRHDE & 5.1 & MXRA5 & 3.0 & TBC1D9 & 2.6 \\
\hline LOC781347 & 4.9 & KCNS3 & 2.9 & SYTL2 & 2.5 \\
\hline RAMP3 & 4.8 & COL8A1 & 2.9 & DOCK4 & 2.5 \\
\hline ENPP6 & 4.7 & CERS6 & 2.9 & PTN & 2.5 \\
\hline$H O P X$ & 4.7 & MOXD1 & 2.9 & ITIH5 & 2.5 \\
\hline ATP8A1 & 4.5 & DYSF & 2.9 & PDLIM1 & 2.5 \\
\hline SHISA9 & 4.3 & $P D E 2 A$ & 2.8 & LOC534200 & 2.5 \\
\hline LOC100337183 & 4.3 & LOC104968548 & 2.8 & PPARG-TSEN2 & 2.5 \\
\hline KCNRG & 4.1 & KCNA4 & 2.8 & CD9 & 2.5 \\
\hline PCOLCE2 & 3.9 & $N D P$ & 2.8 & C1QTNF1 & 2.5 \\
\hline IQGAP2 & 3.8 & KCTD8 & 2.8 & LOXL2 & 2.5 \\
\hline PTGES & 3.8 & VEGFC & 2.8 & GLB1 & 2.5 \\
\hline ADAMTSL4 & 3.8 & RARRES1 & 2.8 & FAM163A & 2.5 \\
\hline CTGF & 3.7 & $F B N 2$ & 2.8 & PHACTR1 & 2.5 \\
\hline IL18 & 3.7 & CXCL16 & 2.8 & MRAP2 & 2.5 \\
\hline PALMD & 3.7 & NEDD9 & 2.8 & CX3CL1 & 2.5 \\
\hline PIEZO2 & 3.6 & TNFRSF $11 B$ & 2.8 & STK17B & 2.5 \\
\hline COL1A1 & 3.5 & $X D H$ & 2.7 & CACNA1G & 2.5 \\
\hline FAM $26 E$ & 3.4 & $H G F$ & 2.7 & ECM1 & 2.4 \\
\hline FAT1 & 3.4 & DPYSL3 & 2.7 & $D A B 2$ & 2.4 \\
\hline THBS1 & 3.4 & OPCML & 2.7 & LOC101903503 & 2.4 \\
\hline SRGAP3 & 3.4 & LOC101908685 & 2.7 & KCND2 & 2.4 \\
\hline RGS16 & 3.3 & $A E B P 1$ & 2.7 & ENC1 & 2.4 \\
\hline PTGER2 & 3.3 & NRIP3 & 2.7 & & \\
\hline CNTNAP3 & 3.3 & COL1A2 & 2.7 & & \\
\hline
\end{tabular}

(Benjamini-Hochberg post hoc test for multiple corrections following one-way ANOVA). The fold change is the ratio of signal intensity of combined pre-theca and interstitial stroma to theca interna from microarray analyses. Differentially regulated genes $(>-2$ fold, $P<0.05)$ were annotated based on the Entrez Gene database. Genes are listed in descending order of fold change.

in the expression of PLN between interstitium and tunica albuginea by qRT-PCR. ACD was significantly downregulated in tunica, interstitium and theca interna compared to pre-theca by microarray analysis and significantly downregulated in theca interna compared to tunica albuginea in qRT-PCR (Fig. 7H). Microarray analysis showed significant downregulation of IL17RD in tunica albuginea, interstitium and theca interna compared to pre-theca (Fig. 7I); however, qRT-PCR did not reveal any differences in gene expression between the stromal compartments. MLF1IP (Fig. 7J) was significantly downregulated in tunica albuginea and theca interna compared to pre-theca; however, qRTPCR revealed no differences for this gene between the stromal compartments.

\section{Protein expression in tunica albuginea, interstitium and theca interna}

In contrast to the results of microarray and qRT-PCR procedures, the expression of osteoglycin by Western blot was found to be significantly upregulated in tunica albuginea and interstitium extracts compared to theca interna (Fig. 8A and $\mathrm{A}^{\prime}$ ). Deglycosylation of osteoglycin in tunica albuginea and interstitium extracts with PNGase $F$, resulted in a molecular weight size reduction from $34 \mathrm{kDa}$ to approximately $25 \mathrm{kDa}$ (Fig. 8A"). Galectin-1 (Fig. 8B and B'), aldehyde dehydrogenase 1 family member $\mathrm{A} 1$ (Fig. 8C and $\mathrm{C}^{\prime}$ ) and adrenocortical dysplasia homolog (Fig. 8D and $\mathrm{D}^{\prime}$ ) showed no differences in the expression between the three tissue types. Phospholamban was significantly downregulated in the theca interna compared to tunica albuginea and interstitium (Fig. 8E and $\mathrm{E}^{\prime}$ ). The results for the negative controls are shown in Supplementary Fig. 1.

\section{Localisation of galectin-1, phospholamban and periostin in bovine adult ovaries}

Galectin-1 was localised in the extracellular matrix of the theca (Fig. 9A) and interstitium (Fig. 9B). Phsopholamban showed a peri-nuclear localised pattern 
Table 7 Top 100 genes differentially downregulated in tunica albuginea compared to stroma (interstitial stroma and pre-theca).

\begin{tabular}{|c|c|c|c|c|c|}
\hline Gene symbol & Fold change & Gene symbol & Fold change & Gene symbols & Fold change \\
\hline TUBA3E & -17.8 & CKS1B & -3.7 & GSTM3 & -2.6 \\
\hline GTSF1 & -10.7 & $Z P 3$ & -3.6 & SOHLH2 & -2.6 \\
\hline$A D A D 1$ & -9.3 & EPCAM & -3.6 & CSRP2 & -2.6 \\
\hline PTTG1 & -7.9 & GDF3 & -3.5 & ODC1 & -2.6 \\
\hline CENPW & -7.7 & $S M C 1 B$ & -3.5 & NOSTRIN & -2.6 \\
\hline GSTA3 & -6.9 & CKS2 & -3.4 & LAMA2 & -2.5 \\
\hline$A \cup R K A$ & -6.4 & MGC133636 & -3.4 & FATE1 & -2.5 \\
\hline LOC104976349 & -5.8 & KPNA2 & -3.3 & LOC783811 & -2.5 \\
\hline RUNDC3B & -5.8 & KCNT2 & -3.2 & TMC5 & -2.5 \\
\hline IGF1 & -5.4 & CCNB3 & -3.2 & TNNI3 & -2.5 \\
\hline FOXR1 & -5.2 & $N E B$ & -3.2 & NNAT & -2.5 \\
\hline$D A Z L$ & -5.1 & $K D R$ & -3.1 & CENPV & -2.5 \\
\hline OSR2 & -5.0 & LHX8 & -3.1 & LOC783613 & -2.5 \\
\hline PHYHIPL & -5.0 & HEY2 & -3.1 & ZNF423 & -2.4 \\
\hline PCSK 2 & -4.9 & HES1 & -3.0 & SALL1 & -2.4 \\
\hline MUC13 & -4.7 & EBF1 & -3.0 & $C P M$ & -2.4 \\
\hline CCDC181 & -4.6 & C23H6orf 25 & -3.0 & CCBE1 & -2.4 \\
\hline CHL1 & -4.6 & LOC537655 & -2.9 & FKBP5 & -2.4 \\
\hline LOC101904481 & -4.5 & $E D N R A$ & -2.9 & $M E T$ & -2.4 \\
\hline SKA1 & -4.5 & TAC3 & -2.9 & CLDN5 & -2.3 \\
\hline UNC13C & -4.4 & ART4 & -2.9 & PECAM1 & -2.3 \\
\hline HIST2H2BF & -4.4 & PHACTR3 & -2.9 & CIART & -2.3 \\
\hline TSPAN13 & -4.4 & CD93 & -2.9 & AGTR1 & -2.3 \\
\hline NPM2 & -4.2 & $\mathrm{CDH7}$ & -2.8 & EPAS1 & -2.3 \\
\hline CHRNA3 & -4.2 & LOC504995 & -2.8 & FBXO15 & -2.3 \\
\hline RGS5 & -4.1 & CENPU & -2.7 & TESC & -2.3 \\
\hline MT3 & -4.1 & ICA1L & -2.7 & SYCP 3 & -2.3 \\
\hline SFRP2 & -3.9 & ABCC9 & -2.7 & LOC101902172 & -2.3 \\
\hline TNFSF18 & -3.9 & GNAO1 & -2.7 & SLC16A10 & -2.3 \\
\hline LMO3 & -3.8 & SGK1 & -2.6 & $E D N R B$ & -2.3 \\
\hline LHX9 & -3.8 & CXADR & -2.6 & WBSCR22 & -2.2 \\
\hline SAXO1 & -3.7 & TGM2 & -2.6 & TGFBR3 & -2.2 \\
\hline LOC100297621 & -3.7 & $A L X 1$ & -2.6 & & \\
\hline LOC519417 & -3.7 & $A B C B 1$ & -2.6 & & \\
\hline
\end{tabular}

(Benjamini-Hochberg post hoc test for multiple corrections following one-way ANOVA). The fold change is the ratio of signal intensity of combined pre-theca and interstitial stroma to theca interna from microarray analyses. Differentially regulated genes $(>2$ fold, $P<0.05)$ were annotated based on the Entrez Gene database. Genes are listed in descending order of fold change.
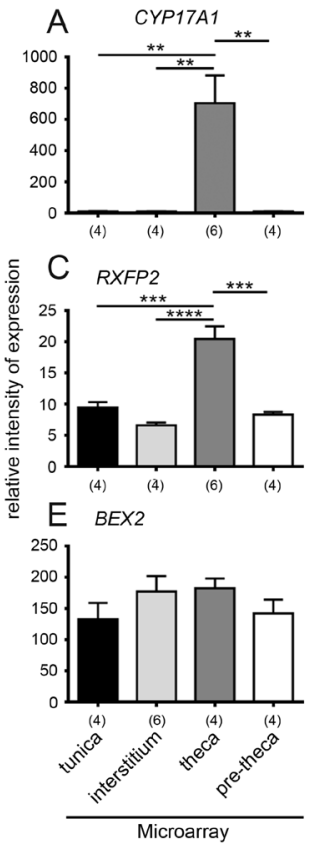

https://rep.bioscientifica.com
B INSL3
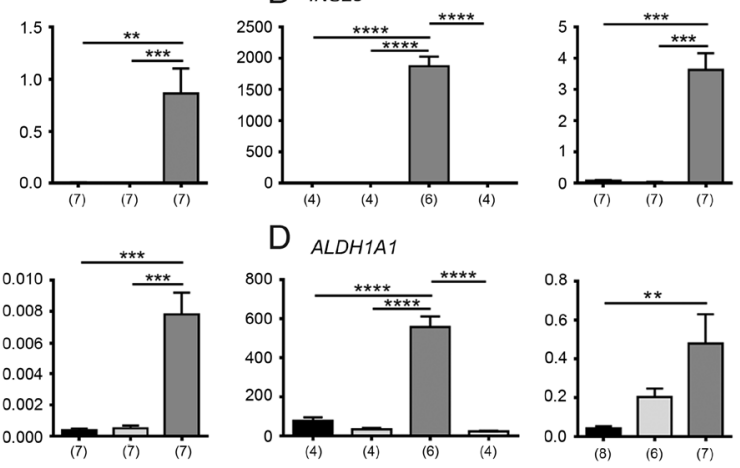

F SREBF2
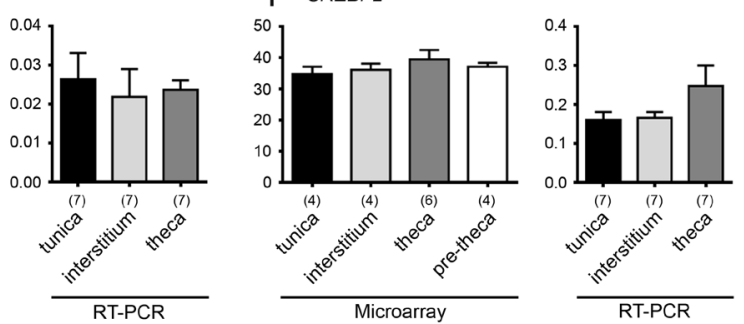

Figure 3 Microarray and qRT-PCR validation data for differentially expressed genes (A-F). The microarray values are signal intensities (normalised, but not log transformed) for tunica albuginea (tunica), interstitial stroma (interstitium), pre-theca and theca interna (theca). qRT-PCR gene expression values were determined from the mean of the ratio of the $\Delta \mathrm{Ct}$ for the target genes to ribosomal protein L19 (RPL19) or L32 (RPL32) and glyceraldehyde phosphate dehydrogenase $(G A P D H)$ and the data are mean \pm S.E.M. Significantly different results for qRT-PCR were determined by one-way ANOVA with Tukey's post hoc test. The microarray signal intensity data were analysed by ANOVA with corrections for multiple testing using the FDR. Number of samples are shown below the graphs in brackets. ${ }^{*} P<0.05,{ }^{* *} P<0.01,{ }^{* * *} P<0.001$, $* * * * P<0.0001$. 
A

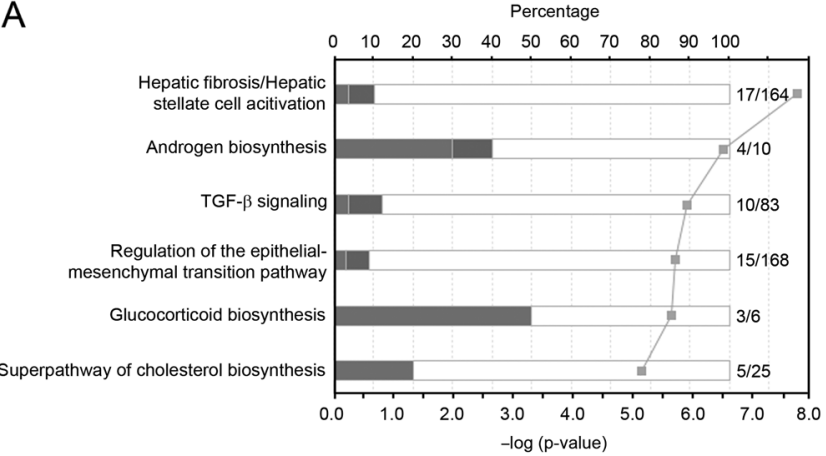

Downregulated in theca interna versus stroma (interstitial stroma and pre-theca) - Upregulated in theca interna versus stroma (interstitial stroma and pre-theca)

B

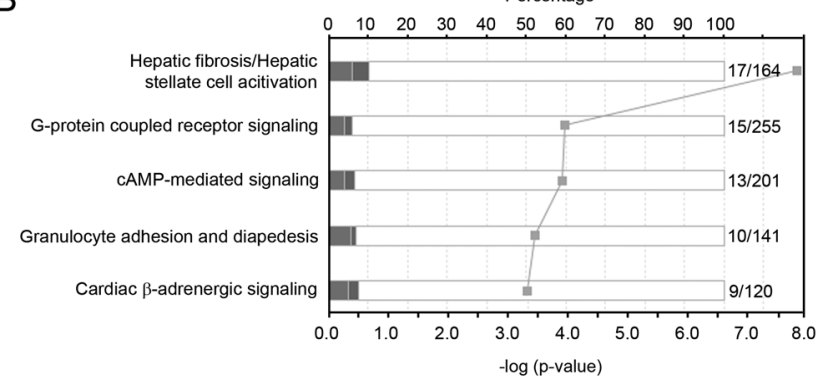

nownregulated in tunica albuginea versus stroma (interstitial stroma and pre-theca) n Upregulated in tunica albuginea versus stroma (interstitial stroma and pre-theca)

Figure 4 Top canonical pathways identified by IPA for the submitted differentially expressed genes for theca interna versus stroma $(A)$ and tunica albuginea versus stroma (B). The bar chart represents the percentage of genes from the data set that map to each canonical pathway showing those which are upregulated (in red) and downregulated (in blue) in theca interna with respect to stroma (A) or tunica albuginea with respect to stroma (B). The line chart ranks these pathways derived for the same data set, from the highest to lowest degree of association based on the value of a right-tailed Fisher's exact $t$ test. The number of differentially expressed genes in the data set and the total number of genes in the canonical pathway are indicated for each pathway on the right hand side.

(Fig. 9C) within vascular smooth muscle cells (Fig. 9D). Periostin localised to the peri-vascular connective tissue sheath of blood vessels within the interstitium (Fig. 9D), as well as the peri-follicular connective tissue (Fig. 9E).

\section{Discussion}

This study focused on the different stromal compartments within the ovary. Four separate areas of stroma were examined but when the principal component analyses revealed that the stroma adjacent to the preantral follicles was similar to interstitial stroma these were combined into one group called 'stroma' for some additional analyses. The major comparisons we made were of stroma versus tunica albuginea and stroma versus theca interna. This is inherently logical as stroma first penetrates the ovary primordium and tunica albuginea develops from that stroma (Hummitzsch
A Cellular Assembly and Organization, Cell Cycle, DNA Replication, Recombination and Repair

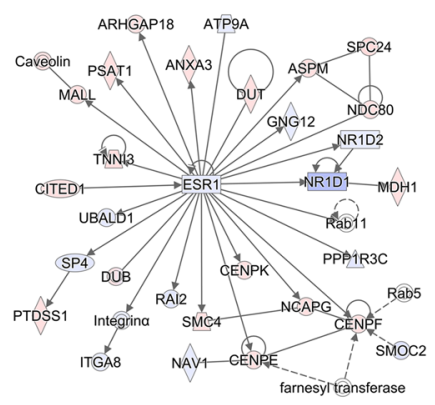

B Cell Cycle, Neurological Disease, Cellular Assembly and Organization

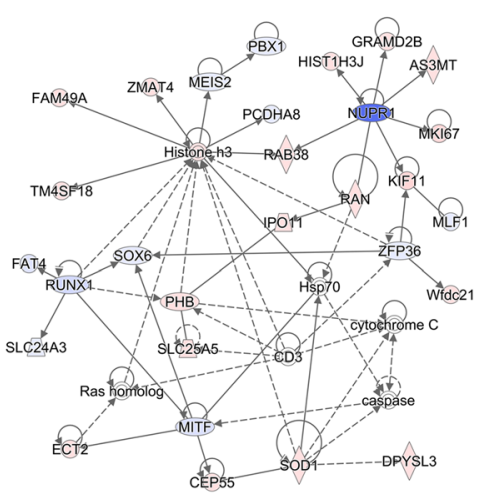

Symbol legend:

$\square$ Cytokine

$\diamond$ Enzyme

(D) Group or Complex

Growth factor

$\triangle$ Phosphatase

- Transcription regulator

0 Transmembrane receptor

G G-protein coupled receptor

$\triangle$ Transporter

$\bigcirc$ other

Connection legend:

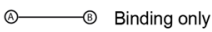

$\longrightarrow$ (1) $\longrightarrow$ Acts on

(A) $\longrightarrow$ I (B) Inhibits and acts on

$\longrightarrow$ Direct interaction

........... Indirect interaction
C Cell Morphology, Cellular Development, Tissue Development

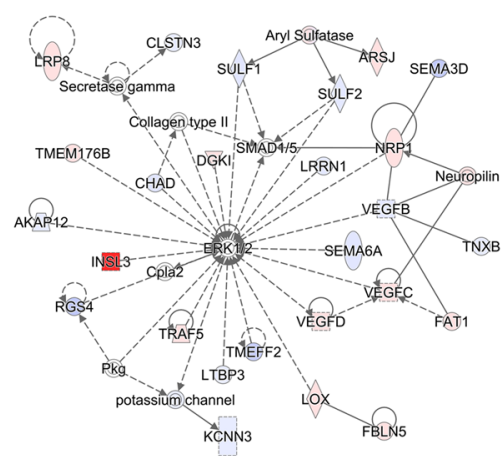

Figure 5 The most significant networks generated by IPA based on the 531 differentially expressed genes between theca interna and stroma (A-C). These networks were generated in IPA using triangular connectivity based on focus genes (those present in our data set) and built up according to the number of interactions between a single prospective gene and others in the existing network, and the number of interactions the prospective genes have outside this network with other genes as determined by IPA (Jolliffe 1986). Interactions between molecules, and the degree and direction of regulation are indicated with upregulation (red) or downregulation (blue) in theca interna and increasing colour intensity with degree of fold change.

et al. 2013, Hummitzsch et al. 2015b). Theca interna differentiates in the stroma area surrounding preantral follicles (Hummitzsch et al. 2015b), suggesting that both tunica albuginea and theca interna are derived at least in part from the stroma. The comparisons we undertook 


\section{A Embryonic Development}

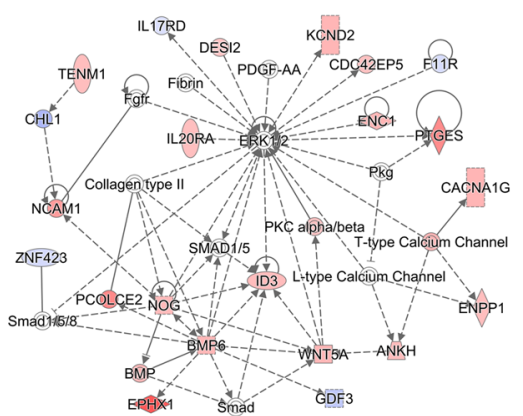

B Cell Morphology

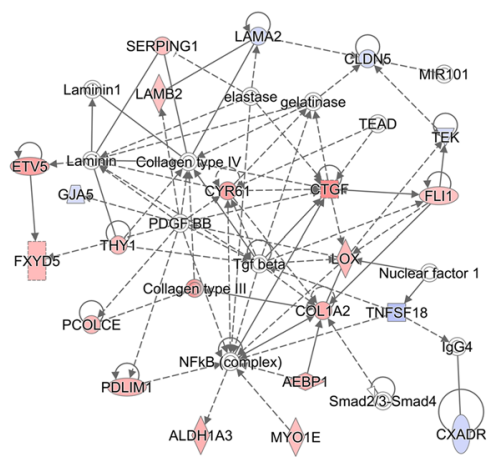

C Organ Morphology

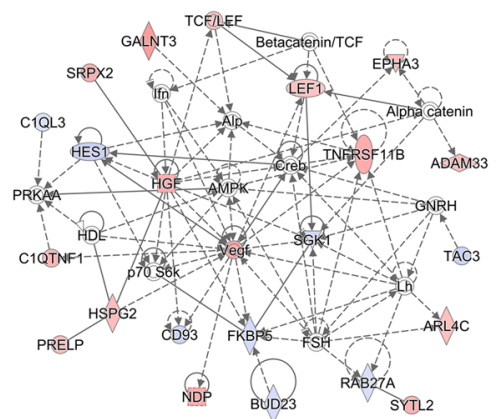

Figure $\mathbf{6}$ The most significant networks generated by IPA based on the 294 differentially expressed genes between tunica albuginea and stroma (A-C). The networks were generated in IPA using triangular connectivity based on focus genes (those present in our data set) and built up according to the number of interactions between a single prospective gene and others in the existing network, and the number of interactions the prospective genes have outside this network with other genes as determined by IPA (Jolliffe 1986). Interactions between molecules and the degree and direction of regulation are indicated with upregulation (red) or downregulation (blue) in tunica albuginea and increasing colour intensity with degree of fold change.

included principal component analyses, ANOVA analyses with post hoc tests for multiple comparisons to identify differentially expressed genes, and then using subsets of highly differentially expressed genes pathway, network and upstream regulator analyses.

The array data were initially confirmed using qRTPCR of six genes using RNA from the laser captured three stromal groups and the dissected theca interna for comparison with RNA isolated from dissected tunica albuginea, interstitial stroma and theca interna (Fig. 3). Excellent agreement was found with tunica albuginea and theca interna comparisons, but less so with interstitial stroma where only five of the six genes examined agreed. A further ten genes were analysed by qRT-PCR and again the differences between tunica albuginea and theca interna were in general agreement with the microarray analyses; however, the results for seven genes in the interstitium were not (Fig. 7). Microdissected interstitium could contain microscopic areas of regressed follicles and corpora lutea, which are easily avoided when undertaking laser capture with the aid of a microscopy but not a visual dissection of the ovary. Thus, the microarray analyses of the arrays are likely to be correct based on the results from the tunica albuginea and the theca interna.

The canonical pathways for theca interna of small antral follicles compared to stroma indicated an upregulation of genes associated with steroid hormone (androgen and glucocorticoid biosynthesis) and cholesterol synthesis with hepatic fibrosis/ hepatic stellate activation and a downregulation of TGF $\beta$ signalling and the epithelial-mesenchymal transition. These are inherently expected as the theca interna is more steroidogenic and less fibrous than the stroma. The pathway of hepatic fibrosis/hepatic stellate activation contains genes indicative of less TGF $\beta$ activity but also upregulation of collagens type IV and XXI which might be associated with increased vascularisation of the theca relative to the stroma. The networks identified include cellular assembly and organisation, the cell cycle and DNA functions and has ESR 1 at its centre and involves downregulation of NR1D1 (transcriptional repressor Rev-erbo) and upregulation of CITED1 (Cbp/p300-interacting transactivator 1). The second pathway was cell cycle and neurological diseases and contained cell death genes like cytochrome C and caspase and protective or cell survival genes like superoxide dismutase 1 (SOD1), heat shock protein 70 (HSP70), prohibitin $(P H B)$ and nuclear protein 1 (NUPR1/RELB/IER3), which are downregulated in theca interna. Upstream regulators were predicted by IPA analyses (Supplementary Table 4). These identified regulators indicate potential pathways and biological processes that could occur in different tissues and cells. They should not be interpreted literally as other related molecules could be the real regulator of these processes; for example, the FSH pathway could also indicate the $\mathrm{LH}$ pathway. Analysing upstream transcriptional regulators revealed 14 activated regulators, including PTGER2 (prostaglandin E receptor 2), CDKN1B (cyclin-dependent kinase inhibitor 1B) and RABL6 (RAS Oncogene Family Like 6) involved in cell cycle, NR5A1 (nuclear receptor subfamily 5 group A member 1; SF1), FSH and MTOR (mechanistic target of rapamycin), and 24 inhibited upstream regulators, 

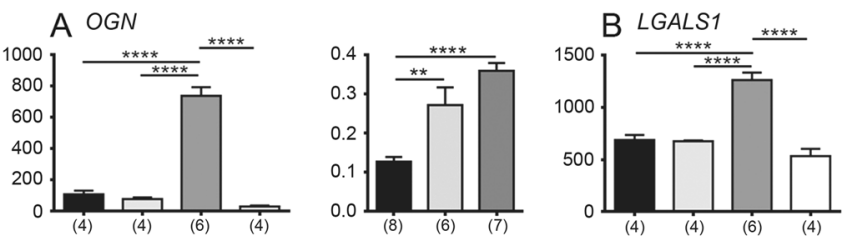

C POSTN
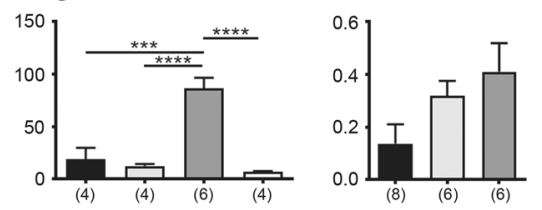

D ASPN
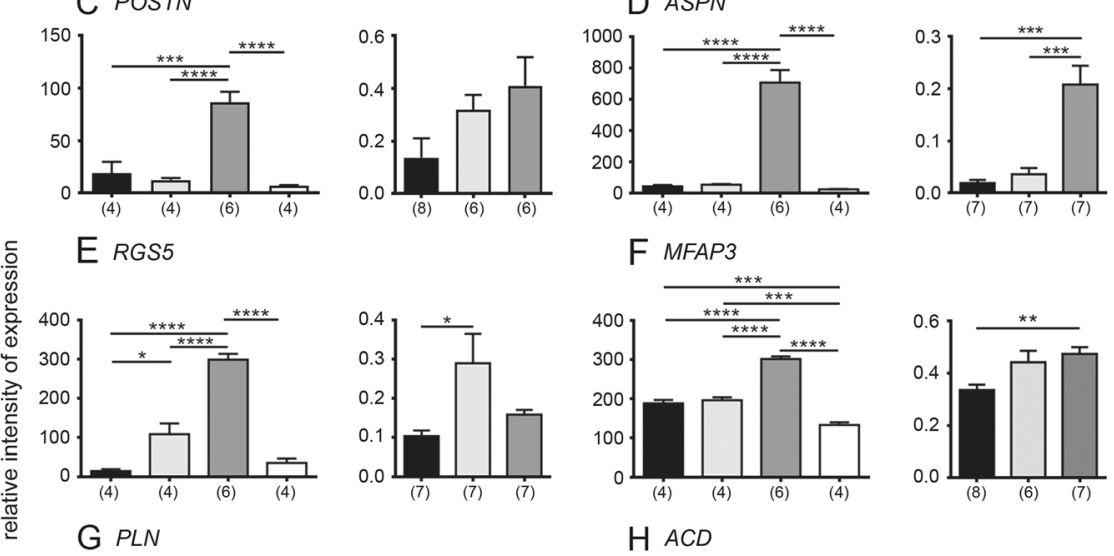

\section{F MFAP3}
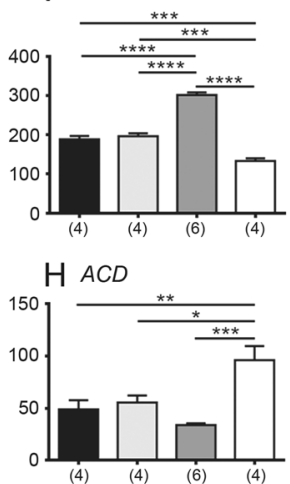

J MLF1IP
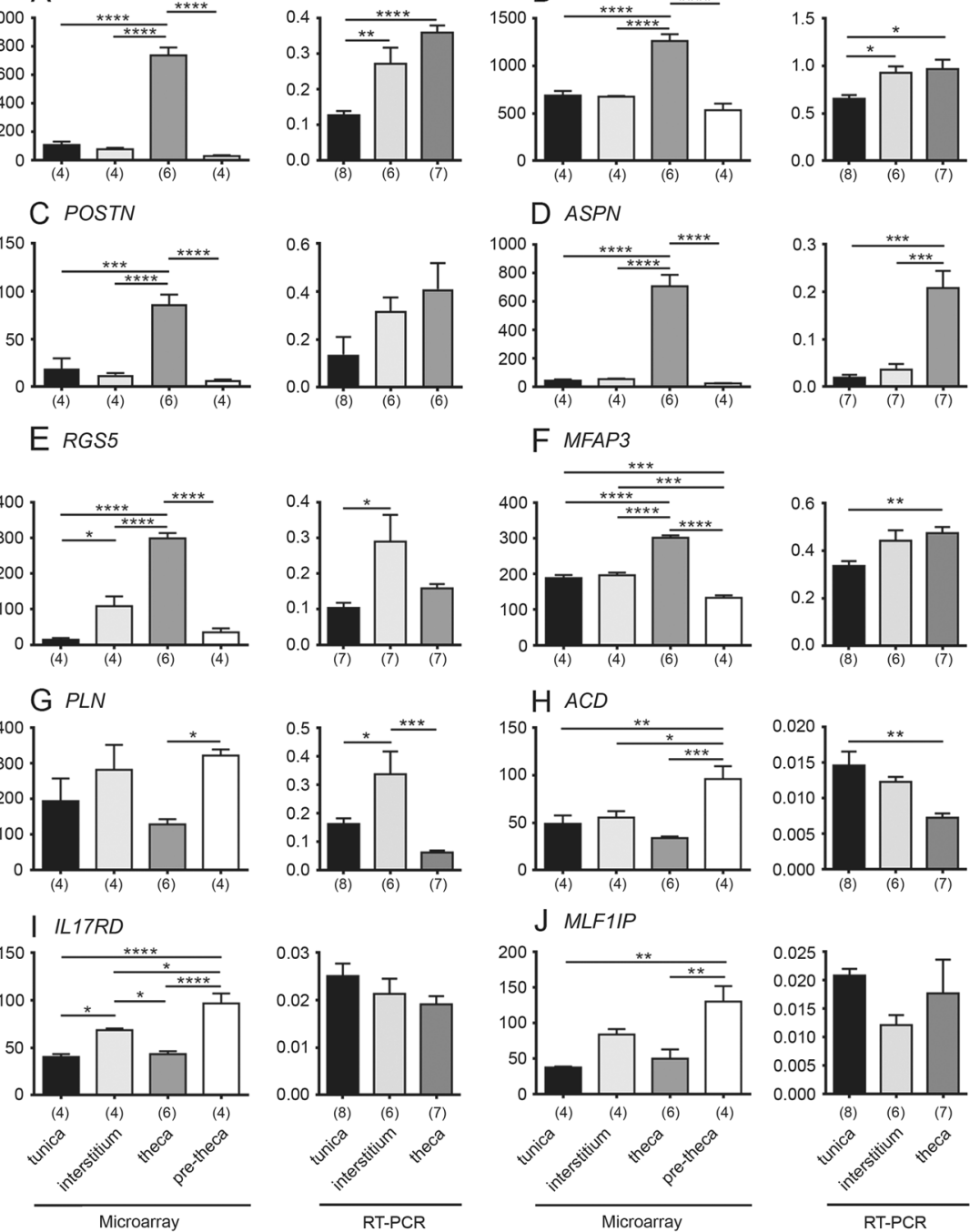

Figure 7 Microarray and qRT-PCR data for differentially expressed genes of interest (A-J). The microarray values are signal intensities (normalised, but not log transformed). qRT-PCR gene expression values were determined from the mean of the ratio of the $\Delta \mathrm{Ct}$ for the target genes to ribosomal protein L19 (RPL19) or L32 (RPL32), and glyceraldehyde phosphate dehydrogenase $(G A P D H)$ and the data are mean \pm S.E.M. Significantly different results for qRT-PCR were determined by one-way ANOVA with Tukey's post hoc test. The microarray signal intensity data were analysed by ANOVA with corrections for multiple testing using the FDR. The number samples are shown below the graphs in brackets. ${ }^{*} P<0.05,{ }^{* *} P<0.01$, $* * * P<0.001, * * * * P<0.0001$. including NUPR1 (nuclear protein 1; involved in cell survival), IL1 (interleukin 1) and TNF (tumour necrosis factor), in the theca interna relative to stroma. These networks and upstream regulators suggest that the theca interna is subject to cell survival pressures. This is not unexpected either as the theca interna undergoes considerable changes during follicular atresia (Clark et al. 2004, Hatzirodos et al. 2014b), whereas the stroma is not a target of atresia.

For the tunica albuginea versus stroma the top conical pathway was associated mainly with hepatic fibrosis/ hepatic stellate activation. The second network on cell morphology contained a number of upregulated extracellular matrix molecules ( $L A M B 1$, collagens type III and IV, COL1A2) and enzymes that process extracellular matrix (elastase, gelatinase, PCOLCE) in the tunica albuginea. The activated upstream regulators were mainly associated with TGF $\beta$ signalling (TGFB1-3, TGFBR1) and the immune system/response (lipopolysaccharide, IL1A, IL10RA, CXCL12, TLR4). This is not unexpected as the tunica albuginea is exceedingly fibrous with much structural collagen, and collagen synthesis is stimulated by TGF $\beta$ (Govinden \& Bhoola 2003, Verrecchia \& Mauviel 2004).

For the tunica albuginea versus stroma dataset, another top canonical pathway included GPCR and CAMP signalling. Furthermore, based on microarray analysis, it is suggested that most of these genes were upregulated in the tunica albuginea compared to stroma. The first network of embryonic development has $E R K 1 / 2$ at its centre but also contains upregulated calcium and potassium channels (CACNA1G, T-type calcium channel, KCND2) and prostaglandin-related genes PDGES (PGE2 synthase) and EPX1 (Epoxide hydrolase 1 that can synthesise arachidonic acid). For tunica albuginea versus stroma based upon IPA analyses, 26 upstream regulators were activated and 16 inhibited, such as SP600125 (JNK inhibitor), docosahexaenoic acid (which can be converted to epoxides and arachidonic acid), the steroid hormone DHEA and ESR1. The upregulation of GPCRs including adrenergic $(A D R A 2 A)$ and cholinergic receptors (CHRM2), CAMP 
A Osteoglycin

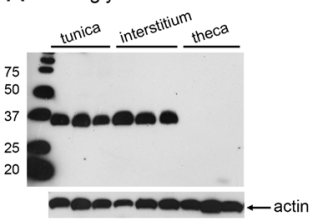

B Galectin-1

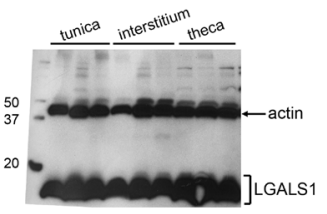

D Adrenocortical dysplasia

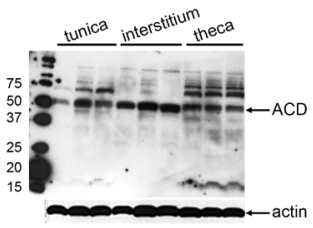

$A^{\prime}$

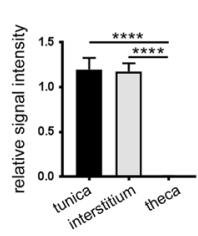

$B^{\prime}$

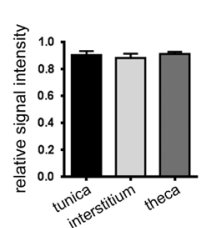

D'

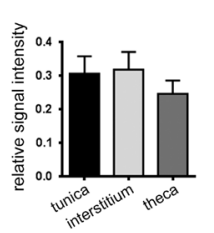

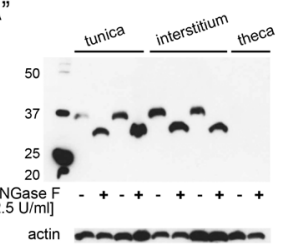

C Aldehyde dehydrogenase $1 \mathrm{~A} 1$

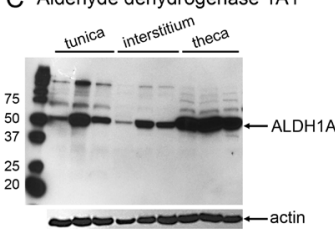

E Phospholamban

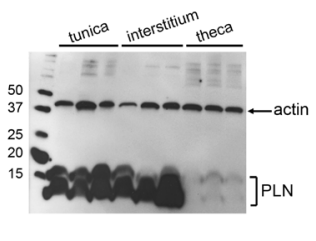

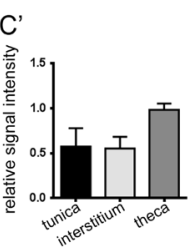

$E^{\prime}$

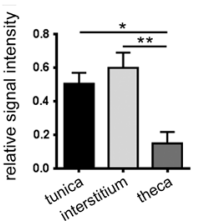

Figure 8 Protein expression for genes of interest. Representative Western immunoblots for (A) osteoglycin (OGN), (B) galectin-1 (LGALS1), (C) aldehyde dehydrogenase 1A1 (ALDH1A1), (D) adrenocortical dysplasia homolog (ACD) and (E) phospholamban (PLN). $\left(A^{\prime}, B^{\prime}, C^{\prime}, D^{\prime}\right.$ and $\left.E^{\prime}\right)$ Quantification of signal intensity relative to $\beta$-actin was performed for tunica albuginea $(n=6)$, interstitial stroma $(n=6)$ and theca interna $(n=24)$. Significantly different results were determined by one-way ANOVA with Tukey's post hoc test. $* P<0.05, * * P<0.01$, ${ }^{* * *} P<0.001$, $* * * * P<0.0001$. Representative Western immunoblot for the deglycosylation of osteoglycin with PNGase $F\left(\mathrm{~A}^{\prime \prime}\right)$. signalling, such as that regulated by prostaglandins, and ion channels suggesting that perhaps the bovine tunica albuginea could be contractile as it is in fish ovarian tunica (Piccinno et al. 2014) and in mammalian testis tunica albuginea (Middendorff et al. 2002). In addition, granulosa cells of preovulatory follicles express endothelin 2 (Ko et al. 2006) causing ovarian contraction (Ko et al. 2006, Bridges et al. 2010).

This study also revealed major differences in the expression levels of genes associated with extracellular matrix proteins and vascular markers between stromal compartments that might be linked to follicle growth, in general, and the preantral-to-antral transition, in particular. Along with biglycan, asporin and decorin are members of the small leucine-rich repeat proteoglycan/ protein (SLRP) class I family (Schaefer \& lozzo 2008). Decorin (DCN) regulates collagen fibrillogenesis (lozzo 1997, Geng et al. 2006, Chen \& Birk 2013) and protects collagen fibrils from cleavage by matrix metalloproteinases (Geng et al. 2006). Microarray analyses are consistent with expression of decorin throughout the ovary, whereas collagen type I was more highly expressed in the theca interna and tunica than the interstitium or pre-theca (Supplementary Table 1). Previously, asporin mRNA has been detected in the testis (Henry et al. 2001) and ovary (Lorenzo et al. 2001, Hatzirodos et al. 2015) and microarray analysis has shown it to be downregulated in cells from the theca following the LH surge (Christenson et al. 2013) and FGF9 treatment (Schutz et al. 2018). Asporin also binds to collagen type I and inhibits fibrillogenesis, having higher affinity for collagen than decorin (Kalamajski et al. 2009). It is expressed by cancer-associated fibroblasts and enhances cell invasion through collagen
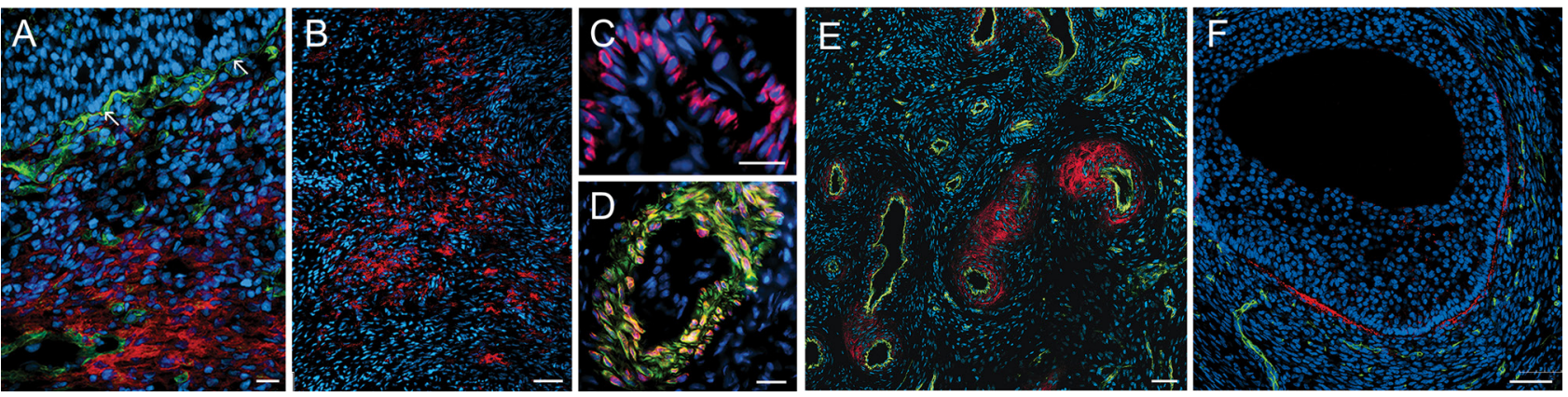

Figure 9 Localisation of galectin-1, phospholamban and periostin in adult bovine ovaries. Galectin-1 (red) is localised to the theca interna (A) and interstitial stroma (B). Arrows in A indicate the follicular basal lamina labelled with an antibody to perlecan (green) (McArthur et al. 2000). Phospholamban (red) showed perinuclear localisation (C) in smooth muscle cells (D) labelled with an antibody to smooth muscle actin (green) Periostin (red) localised to the peri-vascular connective tissue (E) and the theca interna (F), and the endothelium is labelled with lectin (green). Nuclei and labelled with DAPI throughout. Scale bars: A, C and D $=20 \mu \mathrm{m}, \mathrm{B}, \mathrm{E}$ and $\mathrm{F}=50 \mu \mathrm{m}$. 
type I in vitro (Simkova et al. 2016). We found asporin expression to be negligible except within the theca interna. In the ovary, the spatial distribution of SLRPs may facilitate plasticity of the thecal stroma to accommodate the enlargement of growing antral follicles.

Osteoglycin is a member of the SLRP class III family (Schaefer \& lozzo 2008) with functions in several tissues, including bone, skin, hypothalamus and pituitary. Like $D C N$ and MFAP2 (microfibril-associated protein 2), OGN was found by microarray to be overexpressed in thecal cells of dominant bovine follicles compared to granulosa cells (Hatzirodos et al. 2015) or small or large luteal cells (Romereim et al. 2017). Osteoglycin is positively or negatively regulated by a variety of factors, and different mRNA or glycosylated protein variants exist (Deckx et al. 2016). Along with ASPN, FGF9 treatment also downregulated OGN expression in bovine thecal cells (Schutz et al. 2018). Extracellular, osteoglycin binds to collagen type I and conditioned media from myoblastic cells overexpressing osteoglycin increased COL1 expression in osteoblast cells, while underexpression decreases COL1 expression (Tanaka et al. 2012). Osteoglycin has also been localised to endothelial cells and shown to negatively regulate angiogenesis via association with vascular endothelial growth factor receptor 2 (Wu et al. 2017). In contrast to the mRNA levels, osteoglycin protein was not detected in the theca. At this point, we have no explanation for the lack of protein in the presence of a high level of mRNA expression. Absence of osteoglycin from the theca interna may facilitate angiogenesis in the growing antral follicle (Fraser 2006). Osteoglycin and other SLRP family members are regulated by homeobox (HOX) and Runx genes (Tasheva et al. 2004), and HOXA7 (Ota et al. 2006) and RUNX1 (Jo \& Curry 2006) are both expressed by the thecal cells of antral follicles. Our microarray data showed RUNX1, HOXC4 and HOXC8 to be downregulated in the theca compared to the interstitial stroma (see Supplementary Table 1).

A recent microarray study, examining bovine follicle activation in vitro, identified LGALS1 upregulation in primary follicles in comparison to primordial follicles, possibly indicating expansion of the surrounding connective tissue necessary to accommodate the growing follicle (Yang \& Fortune 2015). Galectin-1 is suggested to have a role in luteal regression. In the murine ovary, it is expressed by fibroblasts within corpora lutea undergoing structural regression (Nio-Kobayashi \& Iwanaga 2010), while in the human, it is also expressed by granulosa lutein cells of the mid and late stage corpus luteum (Nio-Kobayashi et al. 2014). However, in the bovine galectin- 1 is localised to the large luteal cells of the healthy bovine corpus luteum, binds to $\mathrm{N}$-glycans on vascular endothelial growth factor receptor-2 and is a survival factor for luteal cells in vitro (Sano et al. 2015). Furthermore, galectin-1 has been shown to inhibit the $\mathrm{FSH}$-stimulated progesterone production of porcine granulosa cells in vitro (Walzel et al. 2004). We found expression of galectin-1 in all compartments measured, with slightly higher mRNA levels in the theca compared to the tunica $(P<0.05)$, but no difference in protein level as measured by immunoblot. Immunohistochemistry revealed that galectin-1 was localised to the extracellular matrix within the interstitium and theca interna, where it may have a role in regulating growth via growth factor binding.

Periostin is another matricellular protein involved in collagen I crosslinking and has been implicated in an number of fibrotic diseases (Kudo 2011) and also has a role in angiogenesis (Kim et al. 2014). It is localised to the epidermal proliferative unit associated with hair follicles important in wound healing (Nishiyama et al. 2011) and is expressed by mesenchymal stromal cells (Coutu et al. 2008). Periostin has also been identified as highly expressed in the stroma of the chicken ovary (Nepomuceno et al. 2015) and upregulated in some ovarian tumours (Tian et al. 2011). We found periostin to be localised to the peri-vascular connective tissue within the interstitium and discontinuously to the peri-follicular connective tissue of some antral follicles, suggesting roles in angiogenesis and follicle growth.

Regulator of G-protein signalling 5 (RGS5), a member of the family of RGS molecules that regulate the signal transduction of G-protein-coupled receptors (GPCRs) and G-proteins, is expressed by pericytes and vascular smooth muscle cells (Bondjers et al. 2003, Cho et al. 2003, Berger et al. 2005). RGS5 has been found to downregulate proliferation of vascular smooth muscle cells in vivo and in vitro (Daniel et al. 2016). Induced expression of RGS5 significantly reduced cell proliferation of ovarian cancer tumour cells in vitro and increased the vascular density in tumours in vivo (Altman et al. 2012). The relatively high expression of RGS5 in the ovarian interstitial tissue found in this study may reflect a role in arteriolar homeostasis in this region. A previous study using LCM and a proteomic approach has identified pathways involved in cardiac muscle contraction as unique to the stromal compartment of the avian ovary (Nepomuceno et al. 2015).

ALDH1A1 (aldehyde dehydrogenase 1 family member A1) provides a source of retinol in the fetal ovary that regulates germ cell meiosis (Bowles et al. 2016) and contributes to follicle development (Kawai et al. 2012, Liu et al. 2018). Granulosa cell expression of ALDH1A1 is upregulated by FSH (Liu et al. 2018); however, it is more highly expressed in the theca interna than the membrana granulosa in follicles from both mice (Kawai et al. 2016) and cows (Hatzirodos et al. 2015). The regulation of $\mathrm{ALDH} 1 \mathrm{~A} 1$ in thecal cells and contribution to follicular development is yet to be determined.

The transcriptional co-activator CITED1 (Cbp/P300 interacting transactivator with Glu/Asp rich carboxyterminal domain 1) has been previously shown to be increased in bovine granulosa cells from large antral 
follicles compared with granulosa cells from small follicles (Hatzirodos et al. 2015). Cited1 is induced by FSH in granulosa cells from human preovulatory follicles (Perlman et al. 2006) and via the progesterone receptor isoform A (PGR-A) in rat and mouse granulosa cells and appears to play a role in the neovascularisation of follicles at the time of ovulation (Sriraman et al. 2010). In our dataset, we observed upregulation of CITED1 in the theca interna relative to stroma and it therefore might be involved in increased vascularisation of the theca interna during follicle growth. Treatment of NIH3T3 cells with TGF $\beta$ results in a transcription-enhancing effect of CITED1 on Smad molecules (Shioda et al. 1998).

CITED1 interacts with the oestrogen receptor $\alpha$ (ESR1) in an oestrogen-dependent manner (Yahata et al. 2001) and ESR1 is mainly expressed in thecal, interstitial and surface epithelial cells (Lee et al. 2009). Specific knockout of ESR1 in the theca interna results in fewer corpora lutea, more antral follicles and more thecal cells and haemorrhage (Lee et al. 2009). ESR1 acts on nuclear receptor subfamily 1 group D members, NR1D1 and NR1D2. Therefore, the downregulation of ESR1 in theca interna in our data set could be responsible for the observed downregulation of both transcription factors in the theca interna. NR1D1 and NR1D2 are negative regulators of core clock proteins (e.g. ARNTL) and play roles in circadian rhythms, lipid and carbohydrate metabolism. NR1D1 modulates the circadian expression of the plasminogen activator inhibitor type I (PA-I), regulates malate dehydrogenase $(\mathrm{MDH} 1)$ linking glycolysis and fatty acid synthesis (Wang et al. 2006) and plays a role in adipocyte differentiation (Laitinen et al. 2005). NR1D1 itself is regulated by inflammation and oxidative stress (Yang et al. 2014) and under the latter condition increases oxidative phosphorylation, mitochondrial biogenesis, anti-oxidative defence and mitochondrial mass by decreasing mitophagy (Sengupta et al. 2016) and thus it could have been expected that NR1D1 would be upregulated in the theca interna and not downregulated as observed.

Prohibitin (PHB) is a member of the highly conserved ubiquitous protein family controlling the cell cycle, differentiation and senescence. Networks generated by IPA revealed upregulation of $P H B$ in the theca interna compared to stroma. Mitochondrial PHB has been shown to be a granulosa cell survival factor regulating anti-apoptotic gene expression (Chowdhury et al. 2016a) and steroidogenesis (Chowdhury et al. 2016b). Overexpression of $P H B$ in adipocytes results in obesity and is associated with elevated serum oestradiol and anovulation in mice (Ande et al. 2017). PHB has been shown to be expressed by theca cells in a stagedependent manner (Thompson et al. 2004), but its specific role in androgen synthesis and cell survival is yet to be investigated in these cells.

Nuclear protein 1 (NUPR1), implicated in the progression of several tumour types, may regulate the expression of many target genes by binding to various transcription factors. Its expression has been shown to be regulated by intracellular $\mathrm{Ca}^{2+}$ (Lee et al. 2015). The granulosa cells of atretic porcine follicles have shown upregulated expression of NUPR1 in comparison to healthy follicles (Terenina et al. 2017). In addition, inactivation of NUPR1 in cancer cells causes mitochondrial dysfunction and is associated with apoptosis and programmed necrosis (SantofimiaCastano et al. 2018). Our IPA network analysis revealed that NUPR1 was downregulated in theca interna compared to stroma, suggesting that it may contribute to the atresia of thecal cells.

MLF1IP, ACD, IL17RD and PLN were identified by microarray as potential markers of the pre-theca; however, these genes were not differentially expressed between stromal compartments. Myeloid leukaemia factor 1-interacting protein MLF1IP (also known as CENPU) is associated with a variety of cancers including ovarian cancer (Li et al. 2018) and was previously found to be expressed in the bovine oocytes (Vallee et al. 2005) and murine follicles and corpora lutea (Wang et al. 2013). Adrenocortical dysplasia protein homolog (ACD) is involved in the maintenance of telomere length and its expression is associated with various tumours (Polito et al. 2018). Mutation of the $A C D$ gene results in reduced follicular development and fertility (Keegan et al. 2005). Similar expression to FGF (SEF or IL17RD) has been localised to the membrana granulosa and theca interna of preovulatory human ovaries (Lutwak et al. 2014). IL17RD inhibits FGF signalling (Tsang et al. 2002), and it is downregulated in cancerous tissues. It has been shown to regulate the epithelial to mesenchyme transition $(\mathrm{He}$ et al. 2016), while overexpression in prostate cancer cells inhibits proliferation (Darby et al. 2009). Together, these genes may have a role in the regulation of cell growth in the ovary. Phospholamban (PLN), a calciumregulating transmembrane sarcoplasmic reticulum phosphoprotein, controls muscle contraction via regulation of sarco(endo)plasmic reticulum calcium ATPase (SERCA) (Gorski et al. 2017). In addition to cardiomyocytes, PLN is found in skeletal (Damiani et al. 2000, Vangheluwe et al. 2005) and smooth muscle (Kim et al. 2008) and endothelial cells where it affects vessel relaxation (Sutliff et al. 1999). PLN also binds to the anti-apoptotic mitochondrial protein HS-1-associated protein X-1 (HAX-1) and may be important in cell survival (Vafiadaki et al. 2009). The role of PLN in the ovary is yet to be elucidated.

In summary, these analyses are in line with known differences between stromal compartments. It is known that the most structural collagen occurs in the tunica albuginea, then the stroma and then the theca interna and our results are in agreements with this. Our results also indicated that the theca interna is steroidogenic as is well known. However, they have also highlighted that the theca interna is regulated by genes associated with 
cell survival and death as this stromal compartment also degenerates when the follicle undergoes atresia.

\section{Supplementary data}

This is linked to the online version of the paper at https://doi.org/10.1530/REP-18-0323.

\section{Declaration of interest}

The authors declare that there is no conflict of interest that could be perceived as prejudicing the impartiality of the research reported.

\section{Funding}

This work was supported by the Australian Research Council (grant number DE120100282), Griffith University and the National Health and Medical Research Council of Australia.

\section{Acknowledgements}

The authors thank Thomas Foods International for the donation of the bovine ovaries and Wendy Bonner for expert technical assistance.

\section{References}

Adib S \& Valojerdi MR 2017 Molecular assessment, characterization, and differentiation of theca stem cells imply the presence of mesenchymal and pluripotent stem cells in sheep ovarian theca layer. Research in Veterinary Science 114 378-387. (https://doi.org/10.1016/j. rvsc.2017.06.021)

Aerts JM \& Bols PE 2010 Ovarian follicular dynamics: a review with emphasis on the bovine species. Part I: Folliculogenesis and pre-antral follicle development. Reproduction in Domestic Animals 45 171-179. (https://doi.org/10.1111/j.1439-0531.2008.01302.x)

Altman MK, Nguyen DT, Patel SB, Fambrough JM, Beedle AM, Hardman WJ \& Murph MM 2012 Regulator of G-protein signaling 5 reduces HeyA8 ovarian cancer cell proliferation and extends survival in a murine tumor model. Biochemistry Research International 2012 518437. (https://doi. org/10.1155/2012/518437)

Ande SR, Nguyen KH, Xu YXZ \& Mishra S 2017 Prohibitin-induced obesity leads to anovulation and polycystic ovary in mice. Biology Open 6 825-831. (https://doi.org/10.1242/bio.023416)

Berger M, Bergers G, Arnold B, Hammerling GJ \& Ganss R 2005 Regulator of G-protein signaling-5 induction in pericytes coincides with active vessel remodeling during neovascularization. Blood 105 1094-1101. (https://doi.org/10.1182/blood-2004-06-2315)

Binder AK, Rodriguez KF, Hamilton KJ, Stockton PS, Reed CE \& Korach KS 2013 The absence of ER-beta results in altered gene expression in ovarian granulosa cells isolated from in vivo preovulatory follicles. Endocrinology 154 2174-2187. (https://doi.org/10.1210/en.2012-2256)

Bocca SM, Billiar RB, Albrecht ED \& Pepe GJ 2008 Oocytes of baboon fetal primordial ovarian follicles express estrogen receptor beta mRNA. Endocrine 33 254-260. (https://doi.org/10.1007/s12020-008-9081-y)

Bondjers C, Kalen M, Hellstrom M, Scheidl SJ, Abramsson A, Renner O, Lindahl P, Cho H, Kehrl J \& Betsholtz C 2003 Transcription profiling of platelet-derived growth factor-B-deficient mouse embryos identifies RGS5 as a novel marker for pericytes and vascular smooth muscle cells. American Journal of Pathology 162 721-729. (https://doi.org/10.1016/ S0002-9440(10)63868-0)

Bonnet A, Bevilacqua C, Benne F, Bodin L, Cotinot C, Liaubet L, Sancristobal M, Sarry J, Terenina E, Martin P et al. 2011 Transcriptome profiling of sheep granulosa cells and oocytes during early follicular development obtained by laser capture microdissection. BMC Genomics 12 417. (https://doi.org/10.1186/1471-2164-12-417)

Bonnet A, Cabau C, Bouchez O, Sarry J, Marsaud N, Foissac S, Woloszyn F, Mulsant P \& Mandon-Pepin B 2013 An overview of gene expression dynamics during early ovarian folliculogenesis: specificity of follicular compartments and bi-directional dialog. BMC Genomics 14904. (https://doi.org/10.1186/1471-2164-14-904)

Bowen NJ, Walker LD, Matyunina LV, Logani S, Totten KA, Benigno BB \& McDonald JF 2009 Gene expression profiling supports the hypothesis that human ovarian surface epithelia are multipotent and capable of serving as ovarian cancer initiating cells. BMC Medical Genomics 271. (https://doi.org/10.1186/1755-8794-2-71)

Bowles J, Feng CW, Miles K, Ineson J, Spiller C \& Koopman P 2016 ALDH1A1 provides a source of meiosis-inducing retinoic acid in mouse fetal ovaries. Nature Communications 7 10845. (https://doi.org/10.1038/ ncomms10845)

Braw-Tal R \& Roth Z 2005 Gene expression for LH receptor, 17 alphahydroxylase and StAR in the theca interna of preantral and early antral follicles in the bovine ovary. Reproduction 129 453-461. (https://doi. org/10.1530/rep.1.00464)

Bridges PJ, Jo M, Al Alem L, Na G, Su W, Gong MC, Jeoung M \& Ko C 2010 Production and binding of endothelin-2 (EDN2) in the rat ovary: endothelin receptor subtype A (EDNRA)-mediated contraction. Reproduction, Fertility, and Development 22, pp. 780-787. (https://doi. org/10.1071/RD09194)

Chen S \& Birk DE 2013 The regulatory roles of small leucine-rich proteoglycans in extracellular matrix assembly. FEBS Journal 280 2120-2137. (https://doi.org/10.1111/febs.12136)

Cho H, Kozasa T, Bondjers C, Betsholtz C \& Kehrl JH 2003 Pericytespecific expression of Rgs5: implications for PDGF and EDG receptor signaling during vascular maturation. FASEB Journal 17 440-442. (https://doi.org/10.1096/fj.02-0340fje)

Chowdhury I, Thomas K \& Thompson WE 2016a Prohibitin( PHB) roles in granulosa cell physiology. Cell and Tissue Research 363 19-29. (https:// doi.org/10.1007/s00441-015-2302-9)

Chowdhury I, Thomas K, Zeleznik A \& Thompson WE $2016 b$ Prohibitin regulates the $\mathrm{FSH}$ signaling pathway in rat granulosa cell differentiation. Journal of Molecular Endocrinology $\mathbf{5 6}$ 325-336. (https://doi. org/10.1530/JME-15-0278)

Christenson LK, Gunewardena S, Hong X, Spitschak M, Baufeld A \& Vanselow J 2013 Research resource: preovulatory LH surge effects on follicular theca and granulosa transcriptomes. Molecular Endocrinology 27 1153-1171. (https://doi.org/10.1210/me.2013-1093)

Clark LJ, Irving-Rodgers HF, Dharmarajan AM \& Rodgers RJ 2004 Theca interna: the other side of bovine follicular atresia. Biology of Reproduction 71 1071-1078. (https://doi.org/10.1095/biolreprod.104.029652)

Coutu DL, Wu JH, Monette A, Rivard GE, Blostein MD \& Galipeau J 2008 Periostin, a member of a novel family of vitamin K-dependent proteins, is expressed by mesenchymal stromal cells. Journal of Biological Chemistry 283 17991-18001. (https://doi.org/10.1074/jbc. M708029200)

Cummings $M$, McGinley CV, Wilkinson N, Field SL, Duffy SR \& Orsi NM 2011 A robust RNA integrity-preserving staining protocol for laser capture microdissection of endometrial cancer tissue. Analytical Biochemistry 416 123-125. (https://doi.org/10.1016/j. ab.2011.05.009)

Damiani E, Sacchetto R \& Margreth A 2000 Variation of phospholamban in slow-twitch muscle sarcoplasmic reticulum between mammalian species and a link to the substrate specificity of endogenous $\mathrm{Ca}(2+)$ calmodulin-dependent protein kinase. Biochimica and Biophysica Acta 1464 231-241. (https://doi.org/10.1016/S0005-2736(00)00153-X)

Daniel JM, Prock A, Dutzmann J, Sonnenschein K, Thum T, Bauersachs J \& Sedding DG 2016 Regulator of G-protein signaling 5 prevents smooth muscle cell proliferation and attenuates neointima formation. Arteriosclerosis, Thrombosis, and Vascular Biology 36 317-327. (https:// doi.org/10.1161/ATVBAHA.115.305974)

Darby S, Murphy T, Thomas H, Robson CN, Leung HY, Mathers ME \& Gnanapragasam VJ 2009 Similar expression to FGF (Sef) inhibits fibroblast growth factor-induced tumourigenic behaviour in prostate cancer cells and is downregulated in aggressive clinical disease. British Journal of Cancer 101 1891-1899. (https://doi.org/10.1038/ sj.bjc.6605379) 
Deckx S, Heymans S \& Papageorgiou AP 2016 The diverse functions of osteoglycin: a deceitful dwarf, or a master regulator of disease? FASEB Journal 30 2651-2661. (https://doi.org/10.1096/fj.201500096R)

Edson MA, Nagaraja AK \& Matzuk MM 2009 The mammalian ovary from genesis to revelation. Endocrine Reviews 30 624-712. (https://doi. org/10.1210/er.2009-0012)

Eisenhart C 1947 The assumptions underlying the analysis of variance. Biometrics 3 1-21. (https://doi.org/10.2307/3001534)

Fraser HM 2006 Regulation of the ovarian follicular vasculature. Reproductive Biology and Endocrinology 4 18. (https://doi. org/10.1186/1477-7827-4-18)

Geng Y, McQuillan D \& Roughley PJ 2006 SLRP interaction can protect collagen fibrils from cleavage by collagenases. Matrix Biology 25 484-491. (https://doi.org/10.1016/j.matbio.2006.08.259)

Glister C, Satchell L, Bathgate RAD, Wade JD, Dai YZZ, Ivell R, AnandIvell R, Rodgers RJ \& Knight PG 2013 Functional link between bone morphogenetic proteins and insulin-like peptide 3 signaling in modulating ovarian androgen production. PNAS 110 E1426-E1435. (https://doi.org/10.1073/pnas.1222216110)

Gorski PA, Ceholski DK \& Young HS 2017 Structure-function relationship of the SERCA pump and its regulation by phospholamban and Sarcolipin. Advances in Experimental Medicine and Biology 981 77-119. (https:// doi.org/10.1007/978-3-319-55858-5_5)

Govinden R \& Bhoola KD 2003 Genealogy, expression, and cellular function of transforming growth factor-beta. Pharmacology and Therapeutics 98 257-265. (https://doi.org/10.1016/S0163-7258(03)00035-4)

Hatzirodos N, Hummitzsch K, Irving-Rodgers HF \& Rodgers RJ 2014a Transcriptome profiling of the theca interna in transition from small to large antral ovarian follicles. PLOS ONE 9 e97489. (https://doi. org/10.1371/journal.pone.0097489)

Hatzirodos N, Irving-Rodgers HF, Hummitzsch K \& Rodgers RJ 2014b Transcriptome profiling of the theca interna from bovine ovarian follicles during atresia. PLOS ONE 9 e99706. (https://doi.org/10.1371/journal. pone.0099706)

Hatzirodos N, Hummitzsch K, Irving-Rodgers HF \& Rodgers RJ 2015 Transcriptome comparisons identify new cell markers for theca interna and granulosa cells from small and large antral ovarian follicles. PLoS ONE 10 e0119800. (https://doi.org/10.1371/journal.pone.0119800)

He Q, Gong Y, Gower L, Yang X \& Friesel RE 2016 Sef regulates epithelialmesenchymal transition in breast cancer cells. Journal of Cellular Biochemistry 117 2346-2356. (https://doi.org/10.1002/jcb.25532)

Henry SP, Takanosu M, Boyd TC, Mayne PM, Eberspaecher H, Zhou W, de Crombrugghe B, Hook M \& Mayne R 2001 Expression pattern and gene characterization of asporin. A newly discovered member of the leucine-rich repeat protein family. Journal of Biological Chemistry 276 12212-12221. (https://doi.org/10.1074/jbc.M011290200)

Honda A, Hirose M, Hara K, Matoba S, Inoue K, Miki H, Hiura H, KanatsuShinohara M, Kanai Y, Kono T et al. 2007 Isolation, characterization, and in vitro and in vivo differentiation of putative thecal stem cells. PNAS 104 12389-12394. (https://doi.org/10.1073/pnas.0703787104)

Hsueh AJ, Kawamura K, Cheng Y \& Fauser BC 2015 Intraovarian control of early folliculogenesis. Endocrine Reviews 36 1-24. (https://doi. org/10.1210/er.2015.36.issue-1.edboard)

Hummitzsch K, Irving-Rodgers HF, Hatzirodos N, Bonner W, Sabatier L, Reinhardt DP, Sado Y, Ninomiya Y, Wilhelm D \& Rodgers RJ 2013 A new model of development of the mammalian ovary and follicles. PLoS ONE 8 e55578. (https://doi.org/10.1371/journal.pone.0055578)

Hummitzsch K, Anderson RA, Wilhelm D, Wu J, Telfer EE, Russell DL, Robertson SA \& Rodgers RJ 2015a Stem cells, progenitor cells, and lineage decisions in the ovary. Endocrine Reviews 36 65-91. (https://doi. org/10.1210/er.2014-1079)

Hummitzsch K, Anderson RA, Wilhelm D, Wu J, Telfer EE, Russell DL, Robertson SA \& Rodgers RJ 2015b Stem cells, progenitor cells and lineage decisions in the ovary. Endocrine Reviews 36 65-91. (https://doi. org/10.1210/er.2014-1079)

Iozzo RV 1997 The family of the small leucine-rich proteoglycans: key regulators of matrix assembly and cellular growth. Critical Reviews in Biochemistry and Molecular Biology 32 141-174. (https://doi. org/10.3109/10409239709108551)

Jimenez R 2009 Ovarian organogenesis in mammals: mice cannot tell us everything. Sexual Development 3 291-301. (https://doi. org/10.1159/000280584)
Jo M \& Curry TE, Jr 2006 Luteinizing hormone-induced RUNX1 regulates the expression of genes in granulosa cells of rat periovulatory follicles. Molecular Endocrinology 20 2156-2172. (https://doi.org/10.1210/ me.2005-0512)

Jolliffe IT 1986 Principal Component Analysis. New York, NY: SpringerVerlag.

Kalamajski S, Aspberg A, Lindblom K, Heinegard D \& Oldberg A 2009 Asporin competes with decorin for collagen binding, binds calcium and promotes osteoblast collagen mineralization. Biochemical Journal 423 53-59. (https://doi.org/10.1042/BJ20090542)

Kawai T, Mihara T, Kawashima I, Fujita Y, Ikeda C, Negishi H, Richards JS \& Shimada M 2012 Endogenous acetaldehyde toxicity during antral follicular development in the mouse ovary. Reproductive Toxicology 33 322-330. (https://doi.org/10.1016/j.reprotox.2012.01.001)

Kawai T, Yanaka N, Richards JS \& Shimada M 2016 De novo-synthesized retinoic acid in ovarian antral follicles enhances $\mathrm{FSH}$-mediated ovarian follicular cell differentiation and female fertility. Endocrinology 157 2160-2172. (https://doi.org/10.1210/en.2015-2064)

Keegan CE, Hutz JE, Else T, Adamska M, Shah SP, Kent AE, Howes JM, Beamer WG \& Hammer GD 2005 Urogenital and caudal dysgenesis in adrenocortical dysplasia (acd) mice is caused by a splicing mutation in a novel telomeric regulator. Human Molecular Genetics 14 113-123. (https://doi.org/10.1093/hmg/ddi011)

Khan DR, Fournier É, Dufort I, Richard FJ, Singh J \& Sirard MA 2016 Meta-analysis of gene expression profiles in granulosa cells during folliculogenesis. Reproduction $\mathbf{1 5 1}$ R103-R110. (https://doi. org/10.1530/REP-15-0594)

Kim M, Hennig GW, Park K, Han IS, Smith TK, Koh SD \& Perrino BA 2008 Modulation of murine gastric antrum smooth muscle STOC activity and excitability by phospholamban. Journal of Physiology 586 4977-4991. (https://doi.org/10.1113/jphysiol.2008.156836)

Kim BR, Jang IH, Shin SH, Kwon YW, Heo SC, Choi EJ, Lee JS \& Kim JH 2014 Therapeutic angiogenesis in a murine model of limb ischemia by recombinant periostin and its fasciclin I domain. Biochimica and Biophysica Acta 1842 1324-1332. (https://doi.org/10.1016/j. bbadis.2014.05.004)

Ko C, Gieske MC, Al-Alem L, Hahn Y, Su W, Gong MC, Iglarz M \& Koo Y 2006 Endothelin-2 in ovarian follicle rupture. Endocrinology 147 1770-1779. (https://doi.org/10.1210/en.2005-1228)

Kudo A 2011 Periostin in fibrillogenesis for tissue regeneration: periostin actions inside and outside the cell. Cellular and Molecular Life Sciences 68 3201-3207. (https://doi.org/10.1007/s00018-011-0784-5)

Laitinen S, Fontaine C, Fruchart JC \& Staels B 2005 The role of the orphan nuclear receptor Rev-Erb alpha in adipocyte differentiation and function. Biochimie 87 21-25. (https://doi.org/10.1016/j.biochi.2004.12.006)

Lee S, Kang DW, Hudgins-Spivey S, Krust A, Lee EY, Koo Y, Cheon Y, Gye MC, Chambon P \& Ko C 2009 Theca-specific estrogen receptoralpha knockout mice lose fertility prematurely. Endocrinology $\mathbf{1 5 0}$ 3855-3862. (https://doi.org/10.1210/en.2008-1774)

Lee YM, Kumar BM, Lee JH, Lee WJ, Kim TH, Lee SL, Ock SA, Jeon BG, Park BW \& Rho GJ 2013 Characterisation and differentiation of porcine ovarian theca-derived multipotent stem cells. Veterinary Journal 197 761-768. (https://doi.org/10.1016/j.tvjl.2013.04.011)

Lee YK, Jee BA, Kwon SM, Yoon YS, Xu WG, Wang HJ, Wang XW, Thorgeirsson SS, Lee JS, Woo HG et al. 2015 Identification of a mitochondrial defect gene signature reveals NUPR1 as a key regulator of liver cancer progression. Hepatology 62 1174-1189. (https://doi. org/10.1002/hep.27976)

Li H, Zhang H \& Wang Y 2018 Centromere protein U facilitates metastasis of ovarian cancer cells by targeting high mobility group box 2 expression. American Journal of Cancer Research 8 835-851.

Liu C, Peng J, Matzuk MM \& Yao HH 2015 Lineage specification of ovarian theca cells requires multicellular interactions via oocyte and granulosa cells. Nature Communications 6 6934. (https://doi.org/10.1038/ ncomms7934)

Liu Z, Sun Y, Jiang Y, Qian Y, Chen S, Gao S, Chen L, Li C \& Zhou X 2018 Follicle-stimulating hormone (FSH) promotes retinol uptake and metabolism in the mouse ovary. Reproductive Biology and Endocrinology 16 52. (https://doi.org/10.1186/s12958-018-0371-9)

Lorenzo P, Aspberg A, Onnerfjord P, Bayliss MT, Neame PJ \& Heinegard D 2001 Identification and characterization of asporin. A novel member of the leucine-rich repeat protein family closely related to decorin and 
biglycan. Journal of Biological Chemistry 276 12201-12211. (https://doi. org/10.1074/jbc.M010932200)

Lutwak E, Price CA, Abramovich SS, Rabinovitz S, Granot I, Dekel N \& Ron D 2014 Expression and regulation of the tumor suppressor, SEF, during folliculogenesis in humans and mice. Reproduction $\mathbf{1 4 8}$ 507-517. (https://doi.org/10.1530/REP-14-0070)

Markholt S, Grondahl ML, Ernst EH, Andersen CY, Ernst E \& LykkeHartmann K 2012 Global gene analysis of oocytes from early stages in human folliculogenesis shows high expression of novel genes in reproduction. Molecular Human Reproduction 18 96-110. (https://doi. org/10.1093/molehr/gar083)

McArthur ME, Irving-Rodgers HF, Byers S \& Rodgers RJ 2000 Identification and immunolocalization of decorin, versican, perlecan, nidogen, and chondroitin sulfate proteoglycans in bovine small-antral ovarian follicles. Biology of Reproduction 63 913-924. (https://doi.org/10.1095/ biolreprod63.3.913)

Middendorff R, Muller D, Mewe M, Mukhopadhyay AK, Holstein AF \& Davidoff MS 2002 The tunica albuginea of the human testis is characterized by complex contraction and relaxation activities regulated by cyclic GMP. Journal of Clinical Endocrinology and Metabolism $\mathbf{8 7}$ 3486-3499. (https://doi.org/10.1210/jcem.87.7.8696)

Monniaux D 2016 Driving folliculogenesis by the oocyte-somatic cell dialog: lessons from genetic models. Theriogenology 86 41-53. (https:// doi.org/10.1016/j.theriogenology.2016.04.017)

Nepomuceno AI, Muddiman DC \& Petitte JN 2015 Global proteomic analysis of functional compartments in immature avian follicles using laser microdissection coupled to LC-MS/MS. Journal of Proteome Research $\mathbf{1 4}$ 3912-3923. (https://doi.org/10.1021/acs.jproteome.5b00346)

Nio-Kobayashi J \& Iwanaga T 2010 Differential cellular localization of galectin-1 and galectin-3 in the regressing corpus luteum of mice and their possible contribution to luteal cell elimination. Journal of Histochemistry and Cytochemistry 58 741-749. (https://doi.org/10.1369/ jhc.2010.956227)

Nio-Kobayashi J, Boswell L, Amano M, Iwanaga T \& Duncan WC 2014 The loss of luteal progesterone production in women is associated with a galectin switch via alpha2,6-sialylation of glycoconjugates. Journal of Clinical Endocrinology and Metabolism 99 4616-4624. (https://doi. org/10.1210/jc.2014-2716)

Nishiyama T, Kii I, Kashima TG, Kikuchi Y, Ohazama A, Shimazaki M, Fukayama M \& Kudo A 2011 Delayed re-epithelialization in periostindeficient mice during cutaneous wound healing. PLOS ONE 6 e18410. (https://doi.org/10.1371/journal.pone.0018410)

Orisaka M, Tajima K, Mizutani T, Miyamoto K, Tsang BK, Fukuda S, Yoshida Y \& Kotsuji F 2006a Granulosa cells promote differentiation of cortical stromal cells into theca cells in the bovine ovary. Biology of Reproduction 75 734-740. (https://doi.org/10.1095/ biolreprod.105.050344)

Orisaka M, Tajima K, Mizutani T, Miyamoto K, Tsang BK, Fukuda S, Yoshida Y \& Kotsuji F 2006 b Granulosa cells promote differentiation of cortical stromal cells into theca cells in the bovine ovary. Biology of Reproduction 75 734-740. (https://doi.org/10.1095/ biolreprod.105.050344)

Ota T, Choi KB, Gilks CB, Leung PC \& Auersperg N 2006 Cell type- and stage-specific changes in HOXA7 protein expression in human ovarian folliculogenesis: possible role of GDF-9. Differentiation; Research in Biological Diversity74 1-10. (https://doi.org/10.1111/j.14320436.2006.00053.x)

Pate JL, Johnson-Larson CJ \& Ottobre JS 2012 Life or death decisions in the corpus luteum. Reproduction in Domestic Animals 47 (Supplement 4) 297-303. (https://doi.org/10.1111/j.1439-0531.2012.02089.x)

Pepling ME Follicular assembly: mechanisms of action 2012. Reproduction 143 139-149. (https://doi.org/10.1530/REP-11-0299)

Perlman S, Bouquin T, van den Hazel B, Jensen TH, Schambye HT, Knudsen S \& Okkels JS 2006 Transcriptome analysis of FSH and FSH variant stimulation in granulosa cells from IVM patients reveals novel regulated genes. Molecular Human Reproduction 12 135-144. (https:// doi.org/10.1093/molehr/gah247)

Piccinno M, Zupa R, Corriero A, Centoducati G, Passantino L, Rizzo A \& Sciorsci RL 2014 In vitro effect of isotocin on ovarian tunica albuginea contractility of gilthead seabream (Sparus aurata L.) in different reproductive conditions. Fish Physiology and Biochemistry 40 1191-1199. (https://doi.org/10.1007/s10695-014-9915-x)
Polito F, Cucinotta M, Abbritti RV, Brogna A, Pergolizzi S, Tomasello C, Barresi V, Angileri FF, Di Giorgio R, Conti A et al. 2018 Silencing of telomere-binding protein adrenocortical dysplasia (ACD) homolog enhances radiosensitivity in glioblastoma cells. Translational Research 202 99-108. (https://doi.org/10.1016/j.trsl.2018.07.005)

Romereim SM, Summers AF, Pohlmeier WE, Zhang P, Hou X, Talbott HA, Cushman RA, Wood JR, Davis JS \& Cupp AS 2017 Transcriptomes of bovine ovarian follicular and luteal cells. Data in Brief 10 335-339. (https://doi.org/10.1016/j.dib.2016.11.093)

Sano M, Hashiba K, Nio-Kobayashi J \& Okuda K 2015 The luteotrophic function of galectin-1 by binding to the glycans on vascular endothelial growth factor receptor-2 in bovine luteal cells. Journal of Reproduction and Development 61 439-448. (https://doi.org/10.1262/jrd.2015-056)

Santofimia-Castano P, Lan W, Bintz J, Gayet O, Carrier A, Lomberk G, Neira JL, Gonzalez A, Urrutia R, Soubeyran P et al. 2018 Inactivation of NUPR1 promotes cell death by coupling ER-stress responses with necrosis. Scientific Reports 8 16999. (https://doi.org/10.1038/s41598018-35020-3)

Scaramuzzi RJ, Baird DT, Campbell BK, Driancourt MA, Dupont J, Fortune JE, Gilchrist RB, Martin GB, McNatty KP, McNeilly AS et al. 2011 Regulation of folliculogenesis and the determination of ovulation rate in ruminants. Reproduction, Fertility, and Development 23 444-467. (https://doi.org/10.1071/RD09161)

Schaefer L \& lozzo RV 2008 Biological functions of the small leucine-rich proteoglycans: from genetics to signal transduction. Journal of Biological Chemistry 283 21305-21309. (https://doi.org/10.1074/jbc.R800020200)

Schutz LF, Hurst RE, Schreiber NB \& Spicer LJ 2018 Transcriptome profiling of bovine ovarian theca cells treated with fibroblast growth factor 9 . Domestic Animal Endocrinology 63 48-58. (https://doi.org/10.1016/j. domaniend.2017.12.002)

Sengupta S, Yang G, O'Donnell JC, Hinson MD, McCormack SE, Falk MJ, La P, Robinson MB, Williams ML, Yohannes MT et al. 2016 The circadian gene Rev-erbalpha improves cellular bioenergetics and provides preconditioning for protection against oxidative stress. Free Radical Biology and Medicine 93 177-189. (https://doi.org/10.1016/j. freeradbiomed.2016.02.004)

Shea LD, Woodruff TK \& Shikanov A 2014 Bioengineering the ovarian follicle microenvironment. Annual Review of Biomedical Engineering $\mathbf{1 6}$ 29-52. (https://doi.org/10.1146/annurev-bioeng-071813-105131)

Shioda T, Lechleider RJ, Dunwoodie SL, Li H, Yahata T, de Caestecker MP, Fenner MH, Roberts AB \& Isselbacher KJ 1998 Transcriptional activating activity of Smad4: roles of SMAD hetero-oligomerization and enhancement by an associating transactivator. PNAS 95 9785-9790. (https://doi.org/10.1073/pnas.95.17.9785)

Simkova D, Kharaishvili G, Korinkova G, Ozdian T, Suchankova-Kleplova T, Soukup T, Krupka M, Galandakova A, Dzubak P, Janikova M et al. 2016 The dual role of asporin in breast cancer progression. Oncotarget 7 52045-52060. (https://doi.org/10.18632/oncotarget.10471)

Simpson KS, Byers MJ \& Curry TE, Jr 2001 Spatiotemporal messenger ribonucleic acid expression of ovarian tissue inhibitors of metalloproteinases throughout the rat estrous cycle. Endocrinology 142 2058-2069. (https://doi.org/10.1210/endo.142.5.8167)

Sriraman V, Sinha M \& Richards JS 2010 Progesterone receptorinduced gene expression in primary mouse granulosa cell cultures. Biology of Reproduction 82 402-412. (https://doi.org/10.1095/ biolreprod.109.077610)

Sutliff RL, Hoying JB, Kadambi VJ, Kranias EG \& Paul RJ 1999 Phospholamban is present in endothelial cells and modulates endothelium-dependent relaxation. Evidence from phospholamban gene-ablated mice. Circulation Research 84 360-364. (https://doi. org/10.1161/01.RES.84.3.360)

Suzuki H, Kanai-Azuma M \& Kanai Y 2015 From sex determination to initial folliculogenesis in mammalian ovaries: morphogenetic waves along the anteroposterior and dorsoventral axes. Sexual Development 9 190-204. (https://doi.org/10.1159/000440689)

Tanaka K, Matsumoto E, Higashimaki Y, Katagiri T, Sugimoto T, Seino S \& Kaji H 2012 Role of osteoglycin in the linkage between muscle and bone. Journal of Biological Chemistry 287 11616-11628. (https://doi. org/10.1074/jbc.M111.292193)

Tasheva ES, Klocke B \& Conrad GW 2004 Analysis of transcriptional regulation of the small leucine rich proteoglycans. Molecular Vision $\mathbf{1 0}$ 758-772. 
Terenina E, Fabre S, Bonnet A, Monniaux D, Robert-Granie C, SanCristobal M, Sarry J, Vignoles F, Gondret F, Monget P et al. 2017 Differentially expressed genes and gene networks involved in pig ovarian follicular atresia. Physiological Genomics 49 67-80. (https://doi. org/10.1152/physiolgenomics.00069.2016)

Thompson WE, Asselin E, Branch A, Stiles JK, Sutovsky P, Lai L, Im GS, Prather RS, Isom SC, Rucker E, 3rd et al. 2004 Regulation of prohibitin expression during follicular development and atresia in the mammalian ovary. Biology of Reproduction 71 282-290. (https://doi.org/10.1095/ biolreprod.103.024125)

Tian Y, Yao Z, Roden RB \& Zhang H 2011 Identification of glycoproteins associated with different histological subtypes of ovarian tumors using quantitative glycoproteomics. Proteomics 11 4677-4687. (https://doi. org/10.1002/pmic.201000811)

Truman AM, Tilly JL \& Woods DC 2017 Ovarian regeneration: the potential for stem cell contribution in the postnatal ovary to sustained endocrine function. Molecular and Cellular Endocrinology 445 74-84. (https://doi. org/10.1016/j.mce.2016.10.012)

Tsang M, Friesel R, Kudoh T \& Dawid IB 2002 Identification of Sef, a novel modulator of FGF signalling. Nature Cell Biology 4 165-169. (https://doi. org/10.1038/ncb749)

Vafiadaki E, Papalouka V, Arvanitis DA, Kranias EG \& Sanoudou D 2009 The role of SERCA2a/PLN complex, $\mathrm{Ca}(2+)$ homeostasis, and antiapoptotic proteins in determining cell fate. Pflugers Archiv 457 687-700. (https://doi.org/10.1007/s00424-008-0506-5)

Vallee M, Gravel C, Palin MF, Reghenas H, Stothard P, Wishart DS \& Sirard MA 2005 Identification of novel and known oocyte-specific genes using complementary DNA subtraction and microarray analysis in three different species. Biology of Reproduction 73 63-71. (https://doi. org/10.1095/biolreprod.104.037069)

Vangheluwe P, Schuermans M, Zador E, Waelkens E, Raeymaekers L \& Wuytack F 2005 Sarcolipin and phospholamban mRNA and protein expression in cardiac and skeletal muscle of different species. Biochemical Journal 389 151-159. (https://doi.org/10.1042/BJ20050068)

Verrecchia F \& Mauviel A 2004 TGF-beta and TNF-alpha: antagonistic cytokines controlling type I collagen gene expression. Cellular Signalling 16 873-880. (https://doi.org/10.1016/j.cellsig.2004.02.007)

Walzel H, Brock J, Pohland R, Vanselow J, Tomek W, Schneider F \& Tiemann U 2004 Effects of galectin-1 on regulation of progesterone production in granulosa cells from pig ovaries in vitro. Glycobiology $\mathbf{1 4}$ 871-881. (https://doi.org/10.1093/glycob/cwh101)

Wang J, Yin L \& Lazar MA 2006 The orphan nuclear receptor Rev-erb alpha regulates circadian expression of plasminogen activator inhibitor type 1. Journal of Biological Chemistry 281 33842-33848. (https://doi. org/10.1074/jbc.M607873200)

Wang X, Marcinkiewicz M, Gatain Y, Bouchard M, Mao J, Tremblay M, Uetani N, Hanissian S, Qi S, Wu J et al. 2013 Investigation of tissuespecific expression and functions of MLF1-IP during development and in the immune system. PLoS ONE 8 e63783. (https://doi.org/10.1371/ journal.pone.0063783)

Woodruff TK \& Shea LD 2011 A new hypothesis regarding ovarian follicle development: ovarian rigidity as a regulator of selection and health. Journal of Assisted Reproduction and Genetics 28 3-6. (https://doi. org/10.1007/s10815-010-9478-4)

Wu QH, Ma Y, Ruan CC, Yang Y, Liu XH, Ge Q, Kong LR, Zhang JW, Yan C \& Gao PJ 2017 Loss of osteoglycin promotes angiogenesis in limb ischaemia mouse models via modulation of vascular endothelial growth factor and vascular endothelial growth factor receptor 2 signalling pathway. Cardiovascular Research 113 70-80. (https://doi.org/10.1093/ cvr/crw220)

Yahata T, Shao W, Endoh H, Hur J, Coser KR, Sun H, Ueda Y, Kato S, Isselbacher KJ, Brown M et al. 2001 Selective coactivation of estrogendependent transcription by CITED1 CBP/p300-binding protein. Genes and Development 15 2598-2612. (https://doi.org/10.1101/ gad.906301)

Yang MY \& Fortune JE 2015 Changes in the transcriptome of bovine ovarian cortex during follicle activation in vitro. Physiological Genomics 47 600-611. (https://doi.org/10.1152/physiolgenomics.00060.2015)

Yang G, Wright CJ, Hinson MD, Fernando AP, Sengupta S, Biswas C, La P \& Dennery PA 2014 Oxidative stress and inflammation modulate Reverbalpha signaling in the neonatal lung and affect circadian rhythmicity. Antioxidants and Redox Signaling 21 17-32. (https://doi.org/10.1089/ ars.2013.5539)

Young JM \& McNeilly AS 2010 Theca: the forgotten cell of the ovarian follicle. Reproduction 140 489-504. (https://doi.org/10.1530/REP-100094)

Received 22 June 2018

First decision 30 July 2018

Revised manuscript received 21 March 2019

Accepted 29 March 2019 